\title{
Control of primary production in the Arctic by nutrients and light: insights from a high resolution ocean general circulation model
}

\author{
E. E. Popova, A. Yool, A. C. Coward, Y. K. Aksenov, S. G. Alderson, B. A. de Cuevas, and T. R. Anderson \\ National Oceanography Centre, Southampton, UK \\ Received: 28 June 2010 - Published in Biogeosciences Discuss.: 19 July 2010 \\ Revised: 3 November 2010 - Accepted: 4 November 2010 - Published: 11 November 2010
}

\begin{abstract}
Until recently, the Arctic Basin was generally considered to be a low productivity area and was afforded little attention in global- or even basin-scale ecosystem modelling studies. Due to anthropogenic climate change however, the sea ice cover of the Arctic Ocean is undergoing an unexpectedly fast retreat, exposing increasingly large areas of the basin to sunlight. As indicated by existing Arctic phenomena such as ice-edge blooms, this decline in sea-ice is liable to encourage pronounced growth of phytoplankton in summer and poses pressing questions concerning the future of Arctic ecosystems. It thus provides a strong impetus to modelling of this region.

The Arctic Ocean is an area where plankton productivity is heavily influenced by physical factors. As these factors are strongly responding to climate change, we analyse here the results from simulations of the $1 / 4^{\circ}$ resolution global ocean NEMO (Nucleus for European Modelling of the Ocean) model coupled with the MEDUSA (Model for Ecosystem Dynamics, carbon Utilisation, Sequestration and Acidification) biogeochemical model, with a particular focus on the Arctic basin. Simulated productivity is consistent with the limited observations for the Arctic, with significant production occurring both under the sea-ice and at the thermocline, locations that are difficult to sample in the field.

Results also indicate that a substantial fraction of the variability in Arctic primary production can be explained by two key physical factors: (i) the maximum penetration of winter mixing, which determines the amount of nutrients available for summer primary production, and (ii) short-wave radiation at the ocean surface, which controls the magnitude of phytoplankton blooms. A strong empirical correlation was
\end{abstract}

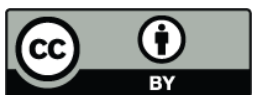

Correspondence to: E. E. Popova (ekp@noc.soton.ac.uk) found in the model output between primary production and these two factors, highlighting the importance of physical processes in the Arctic Ocean.

\section{Introduction}

The summer extent of sea-ice cover in the Arctic has been declining in recent decades. A record minimum of 4.2 million $\mathrm{km}^{2}$ was recorded in September 2007 (e.g., Perovich et al., 2008) compared to a 1979-2000 mean of 7.0 million $\mathrm{km}^{2}$. Given ongoing anthropogenic climate change, this trend is likely to continue, with modelling studies predicting a seasonally ice-free Arctic Ocean (AO) as early as 2050 (Vinnikov et al., 1999; Flato and Boer, 2001; Overland et al., 1995). Diminishing sea-ice cover has important consequences for ecosystem dynamics, associated biogeochemistry and the capacity of the Arctic Ocean to absorb atmospheric $\mathrm{CO}_{2}$. An analysis of satellite-derived primary production by Arrigo et al. (2008) showed that annual production in 2007 exceeded the 1998-2002 mean by $23 \%$. Export of particulate organic carbon may also be enhanced (Lalande et al., 2009), strengthening the biological pump of atmospheric $\mathrm{CO}_{2}$ in the region (Bates and Mathis, 2009). Forecasting how these effects will propagate into the future is however problematic given that we have a limited understanding of the mechanisms controlling present day Arctic Ocean primary production and associated biogeochemistry. Predicting future Arctic productivity changes under conditions of diminishing sea-ice and changes in the water column stratification that ice retreat brings thereby presents a substantial challenge for the modelling community.

The impact of sea-ice on productivity is perhaps most evident through its control of solar irradiance incident on the sea surface. Ice edge blooms are a conspicuous feature in the

Published by Copernicus Publications on behalf of the European Geosciences Union. 
seasonal cycle of Arctic ecosystems (Perette et al., 2010), and potentially the main mode of productivity in this region. These occur when water, rich in nutrients, is first exposed to sunlight during springtime sea-ice melt. At the same time, sea-ice affects vertical stratification by presenting a barrier to cooling and wind-driven mixing of the water column, as well as contributing fresh water during spring and summer time that, reinforced by the riverine fresh water input, inhibits nutrient resupply from below and provides an additional constraint on primary production (Carmack et al., 2006). Studies of production and biogeochemistry in the Arctic need to consider the interacting effects of light regime and nutrient supply, both being affected not only by ice cover but also by water mass structure and the circulation of the region. Carmack et al. (2006) concluded, for example, that whereas ice cover may control the timing of primary production, it is the availability of nutrients that imposes a limit to new production on the interior shelves that are subject to seasonality in ice extent.

The Arctic Ocean experiences extreme seasonality in light regime from permanent darkness during winter to continuous sunlight in summer. Solar elevation remains low even during the summer solstice (only $23.45^{\circ}$ at the North Pole; Sakshaug, 2004). Light availability is also strongly influenced by the presence of ice, with irradiance immediately below the ice (especially that covered by snow) being reduced to $0.2-5 \%$ of surface PAR (Sakshaug, 2004). However, ice concentration is often less than $100 \%$ during the summer months, with a coverage of $80-90 \%$ of winter values even in areas of multi-annual ice (Sakshaug, 2004). Ice cover is interrupted by leads, narrow linear cracks that form when ice floes diverge or shear as they move parallel to each other. Leads typically have a width that varies from a couple of meters to over a kilometer and a life span of hours to days (e.g. Overland et al., 1995; Hutchings, 2008). Thus, two characteristics are of prime importance for the light limitation of phytoplankton: the number of days of open water in the areas of seasonal ice cover, and ice concentration (rather than ice thickness) in the areas covered by the multi-annual ice.

Nitrogen appears to be the primary limiting nutrient in the Arctic as it becomes exhausted first during bloom events (see Tremblay and Gagnon, 2009, and references therein). Phosphorous limitation is however likely in the waters with salinity $<25-26$ PSU because Arctic rivers are relatively rich in nitrogen and silicic acid but poor in phosphate (see Sakshaug, 2004, and references therein). However, the significance of riverine input of nutrients appears to be limited, at least in the present day, because any residual inorganic nutrients are exhausted before the freshwater plume advances into the Arctic Ocean (Tremblay and Gagnon, 2009).

Surface nutrients available for plankton utilisation are supplied by two main mechanisms in the Arctic Ocean: winter mixing and horizontal exchange with the Pacific and Atlantic basins. In addition, there are a number of secondary mecha- nisms that can influence nutrient supply and primary production. For instance, nutrients may be supplied episodically via severe storms and internal waves that erode the halocline (see Yang et al., 2004; Tremblay and Gagnon, 2009; Rainville and Woodgate, 2009, and references therein). In some areas, hydrodynamics in combination with topography can create localised sources of nutrients via processes such as enhanced tidal mixing (e.g. Niebauer and Alexander, 1985), wind-driven shelf-break upwelling (e.g. Mundy et al., 2009), and the turbulent wake behind banks and islands (Sakshaug, 2004). Ice edge upwelling enhances primary production locally and episodically (Mundy et al., 2009), although it may still be of relatively minor importance in the overall supply of nutrients (Niebauer and Smith, 1989; Smith and Niebauer, 1993). Cyclonic eddies have also been shown to impact on primary production in polar areas (Smith and Niebauer, 1993). Their effect can be direct (vertical advection of nutrients) or indirect (adding heat to and altering the circulation of surface waters), both of which decrease sea-ice concentration and enhance available short-wave radiation.

Modelling provides an ideal tool for unifying and quantitatively studying the relative roles of different factors in controlling primary productivity and associated biogeochemistry in the AO. Although a number of regional studies have been conducted focusing on the Chukchi (Walsh et al., 2004, 2005) and Barents (Slagstad and McClimans, 2005; Wassmann et al., 2006; Ellingsen et al., 2008) seas, pan-Arctic biogeochemical modelling studies are only just starting to come to the fore (Lengaigne et al., 2009; Zhang et al., 2010). Despite the use of a range of different ecosystem models for studying the Arctic, there appears to be a general consensus that physical factors impose a strong controlling role on Arctic Ocean productivity. For instance, in a modelling study of biophysical interactions in the Arctic, Smith and Niebauer (1993) suggested that water column stratification is the primary factor in regulating the initiation, development, and dissipation of ice edge phytoplankton blooms.

Here, we investigate the effect of sea-ice and ocean physics as controls on primary production in the Arctic using a global 3-D high resolution coupled physical, biological and ice model. The model is validated for different regions and its suitability assessed in terms of making realistic predictions for the Arctic Ocean. The paper is structured as follows: Sect. 2 presents the model description, forcing specifications and initialisation; Sect. 3 describes model validation for the main ecological provinces and geographical areas; Sect. 4 then gives the main summary of the physical factors controlling Arctic productivity in the model; finally, Sect. 5 provides discussion and conclusions. 


\section{Model description and simulations}

\subsection{Hydrodynamical model}

We make use of the ORCA025-N201 eddy-permitting 19782006 global ocean/sea-ice simulation implemented and performed as part of the European DRAKKAR collaboration (DRAKKAR Group, 2007). The model configuration is based on the NEMO (Nucleus for European Models of the Ocean) code (Madec, 2008), which includes the ocean circulation model OPA9 (Madec et al., 1998) coupled with the Louvain-la-Neuve Ice Model version 2 (LIM2) sea-ice model (Timmermann et al., 2005). The configuration has a $1 / 4^{\circ}$ horizontal resolution $(1442 \times 1021$ grid points) at global scale decreasing poleward (isotropic Mercator grid in the Southern hemisphere, quasi-isotropic bipolar grid in the Northern Hemisphere). The effective resolution is approximately $27.75 \mathrm{~km}$ at the equator, but increases with latitude to be, for example, $\sim 13.8 \mathrm{~km}$ at $60^{\circ} \mathrm{S}$ or $60^{\circ} \mathrm{N}$. The model has 64 vertical levels with a grid spacing increasing from approximately $6 \mathrm{~m}$ near the surface to $250 \mathrm{~m}$ at $6000 \mathrm{~m}$. Bottom topography is represented as partial steps.

The ORCA025-N201 model is driven by the DFS4.1 surface forcing function developed by the DRAKKAR collaboration. As detailed in Brodeau et al. (2010), DFS combines elements from two sources: the CORE forcing data set (Large and Yeager, 2004), from which precipitation, downward shortwave and longwave radiation are extracted; and the ERA40 reanalysis (for the period 1958-2001) which provides $10 \mathrm{~m}$ wind, $2 \mathrm{~m}$ air humidity and $2 \mathrm{~m}$ air temperature to compute turbulent air/sea and air/sea-ice fluxes during model integration using the bulk formulas proposed by Large and Yeager (2004). The frequency of DFS4 is monthly for precipitation, daily for radiation and 6-hourly for turbulent variables. Climatological monthly runoffs (Dai and Trenberth, 2002) are applied along the coastline of the land mask.

Initial conditions for temperature and salinity are derived from a monthly climatology that combines the Levitus et al. (1998) World Ocean Atlas climatology with the PHC2.1 database (Steele et al., 2001) in high latitudes and the Medatlas climatology (Jourdan et al., 1998) in the Mediterranean Sea. To avoid unacceptable drifts in salinity, the sea surface salinity (SSS) is restored toward the monthly mean climatological values. This relaxation timescale is 180 days for the open ocean and 12 days under sea-ice. The model outputs are archived as successive 5-day means throughout the whole integration. More details about the model configuration may be found in Barnier et al. (2009) and Penduff et al. (2007, 2010).

To assess ocean model performance, the simulated oceanic transports through the straits connecting the Arctic Ocean to the Pacific Ocean and to the North Atlantic were compared to the best to date observational transport estimates from the current meter moorings. Table 1 lists transports through the four straits, fully enclosing the Arctic Ocean. It should be
Table 1. Mean simulated and observed oceanic transports through the Arctic straits (Sv). Where possible, the standard deviation of the annual time series is given. Transports into the Arctic Ocean are positive.

\begin{tabular}{lrr}
\hline Strait & Model & Observations \\
\hline Bering Strait & $1.4 \pm 0.2$ & $0.8 \pm 0.2[1]$ \\
Barents Sea Opening & $2.4 \pm 0.2$ & $2.0[2]$ \\
Davis Strait & $-2.8 \pm 0.6$ & $-2.6 \pm 1.0[3]$ \\
Fram Strait & $-1.0 \pm 0.6$ & $-2.0 \pm 2.7[4]$ \\
\hline
\end{tabular}

Key: [1] Melling et al. (2008); [2] Smedsrud et al. (2010); [3] Cuny et al. (2005); [4] Schauer et al. (2008)

noted that the total observed transport through the straits is not zero (Table 1). The residual is attributed to the interannual variability of the flow and to the large uncertainty of the measurements (Curry et al., 2010; Melling et al., 2008; Schauer et al., 2008). Bearing in mind the large uncertainty of the observations, we concluded that the simulations are in reasonable agreement with the observations. The main difference occurs in Fram Strait where the model underestimates the net oceanic outflow from the AO. This is due to an excessive divergence of the Arctic outflow into the Canadian Straits caused by biases in the ECMWF wind forcing fields. The other model bias is in Bering Strait, where the model inflow is about $42 \%$ higher. These model biases are not however detrimental for the purpose of the present study and are not discussed in this paper.

\subsection{Ice model}

The sea ice component is the Louvain-la-Neuve sea-ice model LIM2. A comprehensive description of the model and analysis of its performance are presented in Fichefet et al. (1997) and Timmermann et al. (2005); here we only describe the basic features of the model, relevant to the present study. The LIM2 sea ice model is based on the Viscous-Plastic (VP) ice rheology (Hibler, 1979) and 3-layer (two layers of sea ice and one layer of snow) thermodynamics (Semtner, 1976) with updated model physics. In particular, in addition to Semtner's thermodynamics, the model includes sub-grid scale sea ice thickness distribution, albedo as a function of sea ice thickness (Payne, 1972), and accounts for the presence of open water leads. These features allow more accurate simulation of sea ice growth and melting (Fichefet et al., 1997). To compute advective redistribution of sea ice, the model employs the second order, positive-definite, second moments conserving advection scheme of Prather (1986). In comparison to the other methods, the scheme improves the sea ice simulations by having much smaller numerical diffusion and producing more distinct sea ice edges and a small-scale structure of sea ice fields (e.g. Merryfield and Holloway, 2003). 
The sea ice model is coupled to the ocean model every five oceanic time steps through the non-linear quadratic drag law of the shear between the sea ice velocity and the upperlevel ocean velocity (Timmermann et al., 2005). Following Fichefet et al. (1997), fresh water exchange between the sea ice and ocean is calculated from the sea ice formation/melting, precipitation on the open ocean and snowmelt. In these calculations, sea ice salinity is taken equal to 4 psu, which is the average value of sea ice salinity in the central AO, whereas snowmelt and rainfall are fresh. The sea iceocean heat flux is proportional to the departure of surface temperature from the salinity-dependent freezing point and the friction velocity at the ice-ocean interface. Solar radiation penetrates snowless ice and is trapped by brine pockets inside the sea ice, increasing the latent heat storage of sea ice (Fichefet et al., 1997).

The LIM2 model is used extensively in coarse-resolution global simulations (e.g. Fichefet et al., 1997; Timmermann et al., 2005) as well as in eddy-permitting configurations (Lique et al., 2009). The model demonstrates good skills in simulating the annual cycle, inter-annual variability and multidecadal trends of the Arctic sea ice. The only known bias in high-resolution simulations is slight underestimation of the Arctic summer sea ice extent in comparison to satellite observations (Lique et al., 2009).

\subsection{Ecosystem model}

MEDUSA (Model of Ecosystem Dynamics, carbon Utilisation, Sequestration and Acidification) is an intermediate complexity plankton ecosystem model developed for the global domain. A schematic diagram of the model is presented in Fig. 1. The model includes 11 state variables (Table 2). A detailed model description can be found in Yool et al. (2010).

The model divides the plankton ecosystem into small and large portions, into which different planktonic components are organised. The small portion primarily includes (prokaryotic) nanophytoplankton and microzooplankton (protists and larval metazoans), together with small detrital particles that sink relatively slowly and are explicitly represented. The large portion primarily includes (eukaryotic) diatom phytoplankton and mesozooplankton (adult metazoans), together with large detrital particles that are assumed to sink sufficiently quickly that an implicit representation is required. The phytoplankton state variables are augmented with explicit representations of internal chlorophyll quotas.

MEDUSA is founded on the ocean's nitrogen cycle, and the model resolves 11 state variables distributed between the nitrogen (6 variables), silicon (2 variables) and iron (1 variable) cycles, with the remaining 2 state variables denoting chlorophyll for both of the phytoplankton classes. The silicon cycle is split between dissolved silicic acid and an explicit biogenic opal variable that allows diatom cells to have
Table 2. Model state variables.

\begin{tabular}{lll}
\hline Symbol & Name & Units \\
\hline$P n$ & Non-diatom phytoplankton & $\mathrm{mmol} \mathrm{N} \mathrm{m}^{-3}$ \\
$P d$ & Diatom phytoplankton & $\mathrm{mmol} \mathrm{N} \mathrm{m}^{-3}$ \\
Chl $_{\mathrm{Pn}}$ & Chlorophyll in non-diatoms & $\mathrm{mg} \mathrm{chl} \mathrm{m}^{-3}$ \\
Chl $_{\mathrm{Pd}}$ & Chlorophyll in diatoms & $\mathrm{mg} \mathrm{chl} \mathrm{m}^{-3}$ \\
$P d_{\mathrm{Si}}$ & Diatom phytoplankton (silicon) & $\mathrm{mmol} \mathrm{Si} \mathrm{m}^{-3}$ \\
$Z \mu$ & Microzooplankton & $\mathrm{mmol} \mathrm{N} \mathrm{m}^{-3}$ \\
$Z m$ & Mesozooplankton & $\mathrm{mmol} \mathrm{N} \mathrm{m}^{-3}$ \\
$D$ & Slow-sinking detritus & $\mathrm{mmol} \mathrm{N} \mathrm{m}^{-3}$ \\
$N$ & Dissolved Inorganic Nitrogen (DIN) & $\mathrm{mmol} \mathrm{N} \mathrm{m}^{-3}$ \\
$S$ & Silicic acid & $\mathrm{mmol} \mathrm{Si} \mathrm{m}^{-3}$ \\
$F$ & Iron nutrient & $\mathrm{mmol} \mathrm{Fe} \mathrm{m}^{-3}$ \\
\hline
\end{tabular}

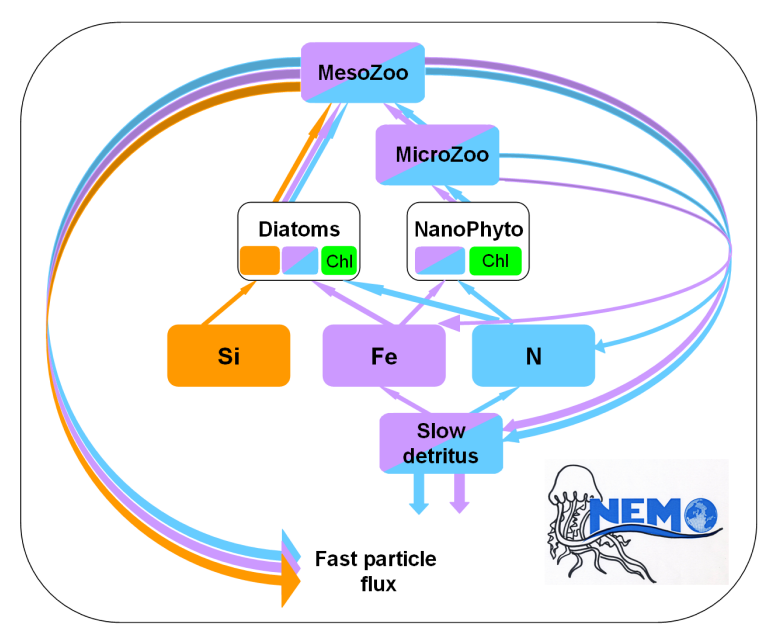

Fig. 1. Schematic diagram of the MEDUSA ecosystem model.

a dynamic Si:N ratio (Mongin et al., 2006). Iron is coupled in a strict Redfield ratio with nitrogen for plankton variables (phytoplankton, zooplankton and detritus), and so requires no separate specification of state variables.

Sinking detrital material occurs in the model in two forms that represent particles of different size, and which are produced and modelled in distinct ways. Small particles are assumed to sink slowly relative to the model timestep, and so their concentration is modelled explicitly as a detritus state variable. Small particles sink under gravity down the water column at a prescribed rate, and are remineralised back to utilisable nutrients at a constant rate. Small particles may additionally be consumed by both micro- and mesozooplankton, which accelerates the return of nitrogen and iron to utilisable forms.

In contrast, large particles of detritus can have sinking velocities that cannot be resolved given the time and space scales of the physical models in which models like MEDUSA are embedded. To resolve this here, the 
concentration of large particles is modelled implicitly, and they are remineralised instantaneously down the water column. At each simulation timestep, the total quantity of large detritus produced by ecosystem processes is integrated down the water column and simultaneously redistributed between the model's vertical levels. This redistribution is based upon the ballast model of Armstrong et al. (2002), and the implementation of this model by Dunne et al. (2007). This model uses the fluxes biogenic opal and calcium carbonate (calculated here as a latitudinal function of primary production) as "ballast" that permits a greater fraction of organic material to reach the deep ocean than the conventional Martin curve (Martin et al., 1987).

\subsection{Model run}

Beginning from rest, the NEMO model was simulated in physics-only mode from 1 January 1978 to 31 December 1987. At this point, MEDUSA's biogeochemistry was coupled to the physics, and the model was then integrated in a fully coupled mode with the evolving physical fields for the period 1 January 1988 to 31 December 2006 inclusive.

For this latter phase, MEDUSA was initialised using the World Ocean Atlas climatology for dissolved inorganic nitrogen and silicic acid concentrations (Conkright et al., 2006). Since it is difficult to quantify and not routinely measured, no such equivalent field exists for the micronutrient iron, and this was instead initialised using an iron field derived from a long-duration simulation of a lower resolution GCM (Parekh et al., 2005, 2006). All other model tracers (phytoplankton, zooplankton, detritus) were initialised to arbitrary small values.

Since they are relatively poorly known, MEDUSA omits riverine and seafloor fluxes of nutrients. To decrease the resulting errors in near-shore nutrient concentrations, the 3-D fields of DIN and silicic acid were relaxed towards World Ocean Atlas climatology values in the coastal zone, defined here as grid cells within $100 \mathrm{~km}$ of the shoreline. This relaxation was full water column, and occurred with a time-scale of 30 days. Because of uncertainties in parameterising the ocean's iron cycle, successfully balancing the addition (aeolian and sedimentary) and removal (scavenging) processes of iron proved difficult in MEDUSA. To this end, iron nutrient was restored towards its initial field for all ocean grid cells more than $100 \mathrm{~km}$ from land, with the same time-scale of 30 days. This ensured that iron was not excessively abundant or limiting during the simulation.

The first 3 years of the simulation (1988 to 1990 inclusive) were considered as a settling period during which the model's state variables diverged from their arbitrary initial values to reach a quasi-repeating annual cycle. The subsequent 15 years of the simulation (1991 to 2006 inclusive) were then used for full analysis. Since no significant consistent trends in the DIN field were detected in the upper ocean over the period of this run (e.g. accumulation or depletion through biological action), we consider this integration time adequate for the purposes of this study.

\subsection{Defining geographical regions and ecological provinces}

Following (Pabi et al., 2008) we define the AO as waters north of the Arctic Circle $\left(66^{\circ} 33^{\prime}\right)$ and divide it into eight geographic sectors and four open water ecological regimes. The geographical sectors are defined by their longitude (Fig. 2) and include the Chukchi $\left(180-160^{\circ} \mathrm{W}\right)$, Beaufort $\left(160-100^{\circ} \mathrm{W}\right)$, Baffin $\left(100-145^{\circ} \mathrm{W}\right)$, Greenland $\left(45^{\circ} \mathrm{W}-\right.$ $\left.150^{\circ} \mathrm{E}\right)$, Barents $\left(15-55^{\circ} \mathrm{E}\right)$, Kara $\left(55-105^{\circ} \mathrm{E}\right)$, Laptev $\left(105-150^{\circ} \mathrm{E}\right)$, and Siberian $\left(150-180^{\circ} \mathrm{E}\right)$ sectors. The four ecological provinces are defined and demarcated following Pabi et al. (2008) and references therein as the pelagic, the shelf, the deepwater marginal ice zone (DMIZ), and the marginal ice zone over the continental shelf (SMIZ). The pelagic and shelf zones are defined as those waters with depth of $>220 \mathrm{~m}$ and $<220 \mathrm{~m}$ and that have remained ice-free for 15 consecutive days. The model grid point is considered part of the MIZ if it remained ice free for less than 15 days. Note that the difference with the 14 day period used by Pabi et al. (2008) results from the fact that all model analysis in this study is based on output fields averaged over five days. To enable direct comparison with the satellite-derived estimates, open water is defined as the model grid with concentration of ice less than $10 \%$. Because of the continuous change in the sea ice extent and concentration, the area of all four ecological provinces varies in time.

\subsection{Conceptual models of Arctic ecosystems}

In this section we describe a conceptual model of the Arctic ecosystem suggested by Sakshaug (2004) and the concept of $\alpha$ and $\beta$ ecosystems proposed by Carmack and Wassmann (2006). Both ideas form a base for initial model validation for the Arctic region and are widely used in the interpretation of our results in later sections.

A conceptual model of the annual cycle of Arctic production is as follows (Sakshaug, 2004). Nutrients available for primary productions in the mixed-layer depth at the end of winter are set by wintertime convection and circulation including upwelling at the shelf break. Melting of the sea ice and input of fresh water by rivers establish stable shallow stratification which sets conditions for the spring bloom. Limited availability of nutrients and a stable shallow upper mixed layer (UML) confines the extremely intense (up to $20 \mathrm{mg} \mathrm{Chl}-a \mathrm{~m}^{-3}$ ) but short-lasting Chl- $a$ bloom to the retreating ice edge forming a $30-100 \mathrm{~km}$ wide band of high Chl- $a$ (e.g. Sakshaug, 2004). The retreat of the ice cover controls the timing of the spring bloom while zooplankton grazing and UML depth determine its magnitude and the availability of nutrients its duration. In autumn, an increase in nutrient supply due to enhanced vertical mixing may trigger 


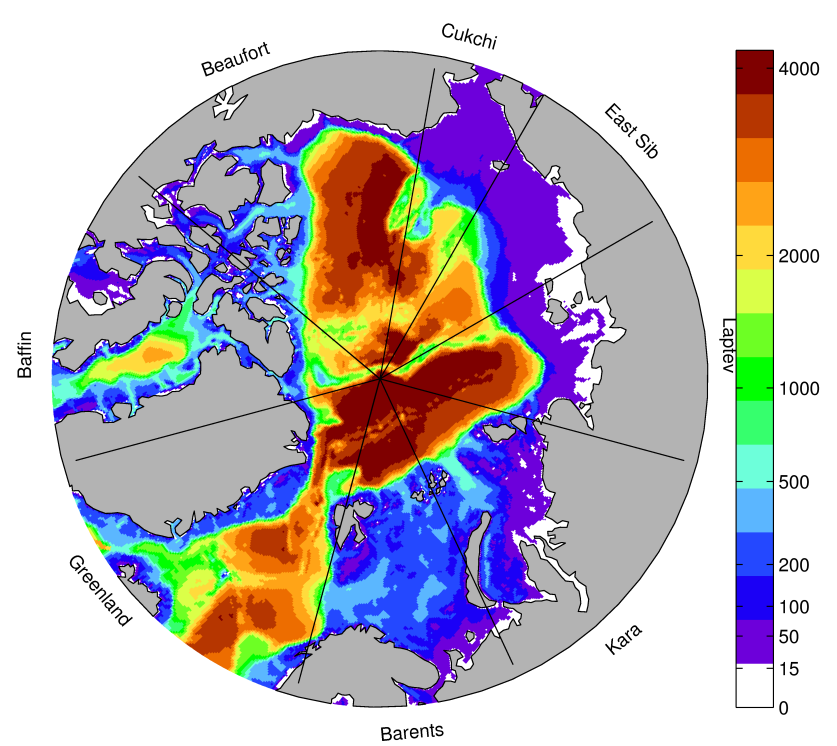

Fig. 2. Bottom topography $(\mathrm{m})$ and boundaries of geographical sectors.

a weaker phytoplankton bloom although observational evidence of ecosystem dynamics for this time of year do not exist. It has also been observed that an accumulation of plankton biomass can occur in the bottom 3-4 cm of the ice (Melnikov et al., 2002).

Primary production is determined by a complex interplay between availability of light and nutrients both regulated by the stratification. In this respect Carmack and Wassmann (2006) suggested the concept of $\alpha$ and $\beta$ oceans (after $\alpha$, the thermal expansion coefficient, and $\beta$, the haline contraction coefficient). Temperature stratification is of primary significance in $\alpha$ type waters and typical of the tropical and subpolar ocean. $\beta$-type waters with a predominant salinity stratification are typical of the polar areas affected by ice formation and melting. At present the Arctic Ocean consists mostly of $\beta$-type waters, except for the Atlantic inflow (Barents sea). The different mixing regimes in $\alpha$ and $\beta$ oceans support contrasting ecosystem regimes and, as far as biophysical feedback is concerned, present a different intensity of feedback between physics and biology. Substantially deeper mixing of the $\alpha$ oceans supports phytoplankton concentrations much lower than the shallow stable surface layers of the $\beta$ oceans. However increased vertical mixing in $\alpha$ type waters results in much higher integrated primary production than the intense but shallow blooms of the $\beta$ oceans. On an annual basis, the situation in $\alpha$ and $\beta$ oceans becomes even more contrasting: $\beta$ blooms are transient and quickly become nutrient limited, while high productive $\alpha$ regimes are sustained for long periods of time due to continuous re-supply of nutrients. The contrasting nature of $\alpha$ and $\beta$ ecosystems can be illustrated by the comparison of south-eastern and northern areas of the Barents Sea where respective Chl- $a$ maxima are
5 vs. $20 \mathrm{mg} \mathrm{Chl}-a \mathrm{~m}^{-3}$, with annual primary production of 200 vs. 30-60 $\mathrm{g} \mathrm{C} \mathrm{m}^{-2} \mathrm{yr}^{-1}$ (Wassmann et al., 2006).

\section{Results}

\subsection{Light regime of the AO}

In the simulations, the total Arctic sea-ice extent (defined as the total area covered by sea-ice) and the sea-ice area (defined as the integral of the fraction of the area covered by sea-ice) are in good agreement with satellite-derived fields (Rayner et al., 2003). Overall, the average (1980-2001) total simulated Arctic sea-ice extent differs from observations by no more than $5 \%$ in the winter and no more than $10 \%$ in the summer, although some regional departures are larger, of the order of $20 \%$. The modelled summer sea-ice agrees better with the observed field than in the corresponding DRAKKAR run G70 (Lique et al., 2009). The improvement is mostly because of the use of new atmospheric forcing fields from DFS 4.1 (Brodeau et al., 2010).

The observed (Rayner et al., 2003) and modelled numbers of days of open water for year 1997, as well as average summer (June, July, August) ice concentrations, are compared in Fig. 3. In general, the patterns seen in the spatial distribution of the number of open water days in the model and data show good agreement. The largest (in units of area) discrepancy between the observed and modelled distributions occurs in the Greenland sector where the modelled sea-ice zone extends too far east from the East Greenland Shelf. The cause for the bias is the excessive ammount of cold, buoyant Arctic surface waters present in the western Greenland Sea in the simulations, resulting in strong stratification of the water column. This reduces oceanic heat towards the sea-ice base and decreases sea-ice ablation. Another model bias occurs in the south-eastern Barents Sea, where there is more seaice in the summer than that observed. This is because the simulated Atlantic water inflow in the western Barents Sea is colder than the observed, consequently about $20 \%$ less heat is available to melt sea ice. However the sea ice bias is not of significance for this study, as its concentration and thickness are low, less than 0.20 and less than $10 \mathrm{~cm}$ respectively.

As already noted, the annual input of short-wave radiation to the ocean depends on ice fraction rather than on ice thickness, even in areas covered by multi-annual ice. Summer averaged ice concentration in the central Arctic Ocean varies between 80 and $95 \%$ in the model, with localised minima of about $75 \%$ (Fig. 3c). These concentrations are lower than observed values of $>95 \%$ (Fig. 3d), and this underestimation of ice concentration leads to an equivalent overestimation of short-wave radiation and therefore also the photosynthetically active radiation (PAR) available to phytoplankton. The reduced sea-ice cover simulated in the Central Arctic is likely to be caused by positive biases in the downwelling short-wave radiation and surface air temperature fields in the 


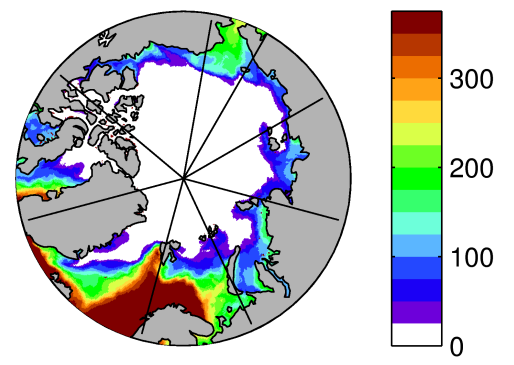

a) Days of open water (model)

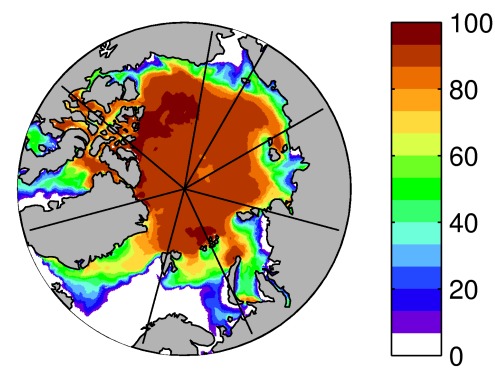

c) Summer ice concentration (model)

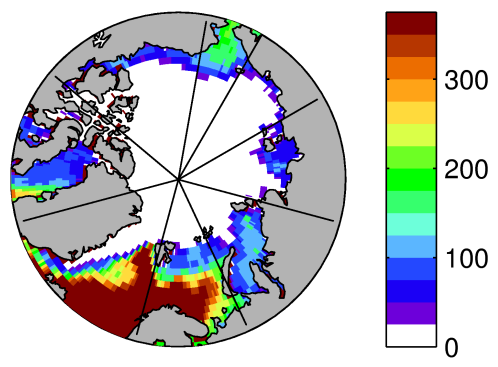

b) Days of open water (data)

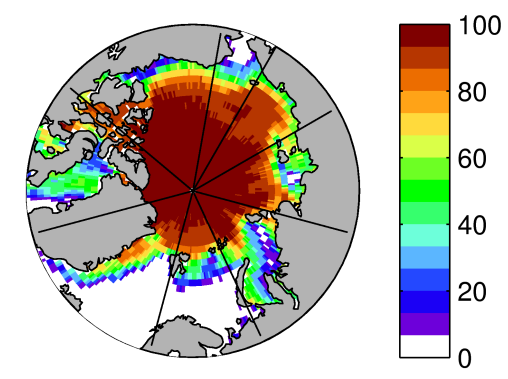

d) Summer ice concentration (data)

Fig. 3. Modelled (a) and observed (b) days of open water; modelled (c) and observed (d) summer (June, July, August) average ice concentration for year 1997.

DFS4.1 data set used to force the model (Brodeau et al., 2010). This bias is not significantly detrimental for the simulation of physics in the upper and intermediate ocean, but may cause light regime to be unduly favourable for primary production.

The observed annual mean open water (ice-free) area for 1998-2005 comprises about $30 \%$ of the total area of the AO. The model tends to overestimate the extent of sea-ice, with the area of open water varying between only 19 and $23 \%$. Similarly, the model underestimates the annual mean marginal ice zone with a coverage of just $1.9 \%$ of the total $\mathrm{AO}$ area as compared to $8.5 \%$ in the observations.

Surface short-wave radiation averaged over the productive period (May-September) is shown in Fig. 4a. It shows a decline poleward as a result of increasing ice thickness and concentration and reduction in solar elevation. The maximum short-wave radiation occurs along the shelf where ice-free conditions occur in summer and in the permanentlt ice-free areas affected by the Atlantic inflow.

\subsection{Nutrient regime of the AO}

Since the horizontal resolution employed in this study is insufficient to permit localised nutrient supply mechanisms described in the introduction, the model is unable to describe small-scale or episodic "hot-spots" of productivity (such as that seen near Svalbard; e.g. Sakshaug, 2004). As a result, our analysis is focused on the two large-scale mechanisms of nutrient supply: winter mixing and horizontal exchange.

The strong salinity stratification found over most of the Arctic domain restricts vertical mixing (e.g. Rudels et al., 1996) and thus vertical supply of nutrients. In addition, ice cover isolates the underlying water column from the influence of wind forcing and provides strong negative buoyancy forcing that prevents the development of winter convection. The modelled maximum depth of the UML shows these features (Fig. 4c). Deep winter mixing (in excess of $300 \mathrm{~m}$ ) in the model occurs only in the Atlantic inflow waters in the south-east Greenland and south-west Barents sectors. Winter mixing rarely exceeds $80 \mathrm{~m}$ outside of these areas, and on average is only $40 \mathrm{~m}$. Mixing does not penetrate deeper than $20 \mathrm{~m}$ throughout the year on the Siberian shelves which are affected by significant input of fresh water from rivers. Various studies have shown that sea-ice melting and river input of fresh water establish a shallow spring-summer UML of 15$35 \mathrm{~m}$ depth, separated from underlying waters by a strong seasonal halocline (Sakshaug, 2004; Rudels et al., 1996) that severely limits episodic resupply of nutrients during intensive storm events (cf. Fig. 4b).

Cascading of shelf waters to intermediate depths, down to $1000 \mathrm{~m}$, has been recorded in several locations off the Barents Sea and Siberian shelves (e.g. Ivanov and Shapiro, 2005; Ivanov and Golovin, 2007). This process may change ocean stratification and erode the pycnocline, although only a few cascading regions around the Arctic shelf have been 


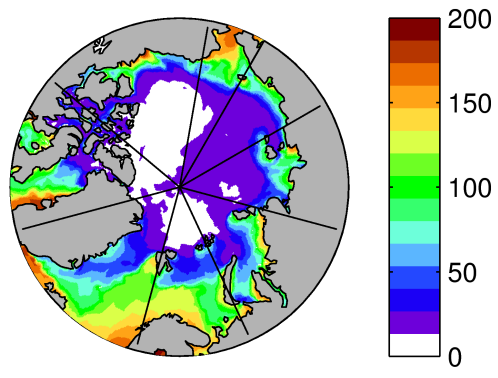

a) Summer SW rad surface

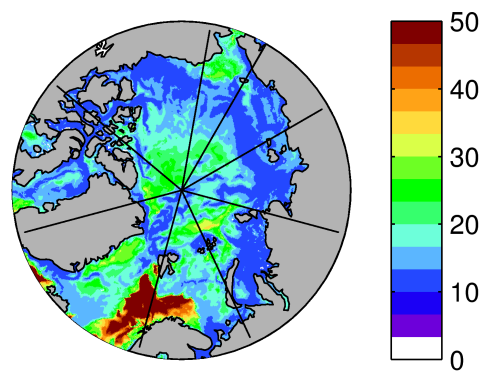

c) UML (summer)

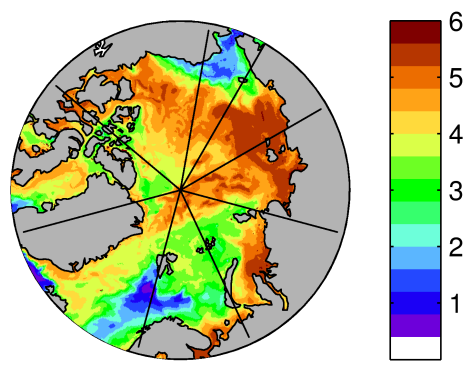

b) UML annual SW rad (summer)

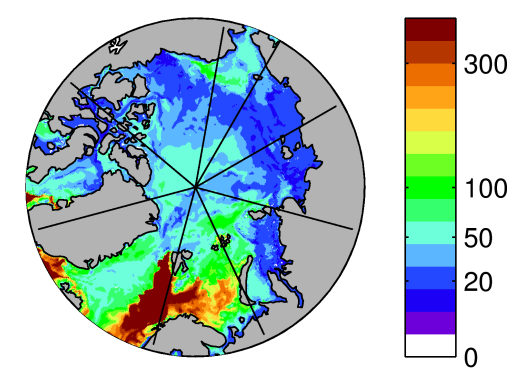

d) Max UML

Fig. 4. Model results for year 1997: (a) Summer (May-September) average short-wave radiation at the ocean surface $\mathrm{W} \mathrm{m}^{-2}$ ); (b) summer (May-September) average UML depth (m); (c) maximum modelled depth of UML during the year (note non-linear colour scale) on the basis of 5 day average values $(\mathrm{m})$.

discovered so far and basin-wide implications of the cascading are not yet fully understood. Despite the model realistically simulating cascading of the Barents Sea bottom water in to the Eurasian Arctic Ocean, it is likely to under represent shelf cascading, as the higher model resolution, ca. $2 \mathrm{~km}$, is required to properly resolve this process (e.g. Ivanov and Golovin, 2007). However, since this is a relatively localised phenomenon, its absence in the model is not detrimental for the present study.

The modelled maximum surface concentrations of DIN and silicate are shown in Fig. 5a, b. DIN and silicate were initialised from the WOA. The model does not drift substantially from the initial state and reproduces well the observed contrasting features of the Pacific and Atlantic inflow (Conkright et al., 2006). The subarctic Pacific Ocean and the deep Bering Sea are characterised by some of the highest levels of nutrients seen in the world ocean with deep (below the pycnocline) concentrations of $30-40 \mathrm{mmol} \mathrm{m}^{-3}$ for nitrate and $100-300 \mathrm{mmol} \mathrm{m}^{-3}$ for silicic acid (see Sakshaug, 2004, and references therein), as compared with $10-15 \mathrm{mmol} \mathrm{m}^{-3}$ for nitrate and 6-8 $\mathrm{mmol} \mathrm{m}^{-3}$ in the North Atlantic sector. However, restricted vertical mixing in the North Pacific, in combination with the shallow depth of the Bering strait (40$50 \mathrm{~m}$ ), prevents penetration of these nutrient-rich waters into the Arctic basin. The winter maximum of nutrients in sur- face waters of the northern Bering sea is nevertheless significant, with concentrations of $10-15 \mathrm{mmol} \mathrm{m}^{-3}$ for nitrate and $20-25 \mathrm{mmol} \mathrm{m}^{-3}$ for silicic acid, in part because concentrations of the micronutrient iron prevents the drawdown of macronutrients to corresponding North Atlantic concentrations (e.g. Tsuda et al., 2003). Given these differences in winter maximum silicic acid and nitrate values in Pacific and Atlantic inflow waters, the model Si:N ratio varies significantly across the Arctic basin and creates strong gradients in phytoplankton community composition exemplified by dominance in the model of diatoms in the Chukchi sector.

The modelled annual minima of surface silicate and DIN are shown in Fig. 5c, d, indicating where primary production in the UML is limited by nutrients rather than availability of light. Productivity in the UML in these areas is likely to be relatively unchanged if ice retreat continues without an accompanying weakening of the stratification. It would appear that the majority of the shelf areas, as well as central Arctic, are limited by DIN. Exceptions where light limitation is important include the Pacific inflow (Chukchi sector), Greenland sector, and areas adjacent to the Canadian Archipelago where ice thickness and concentration are maximal. 


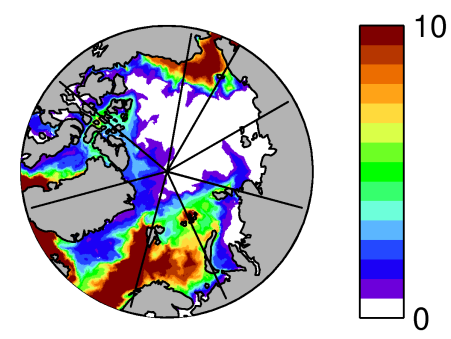

a) Maximum DIN

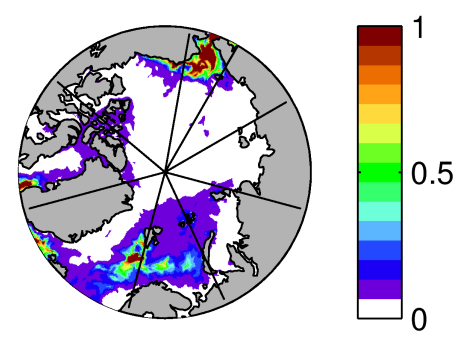

c) Minimum DIN

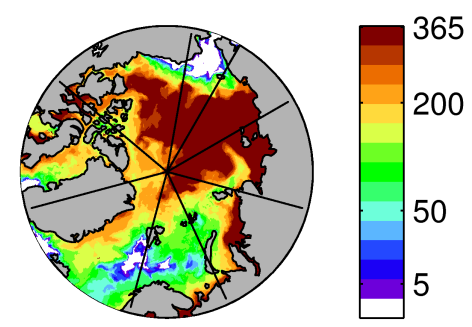

e) Days of DIN limitation

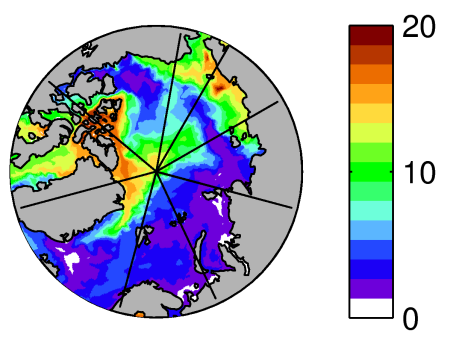

b) Maximum silicate

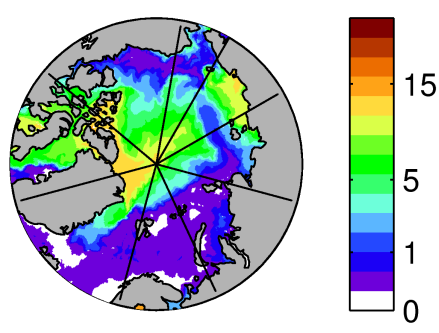

d) Minimum silicate

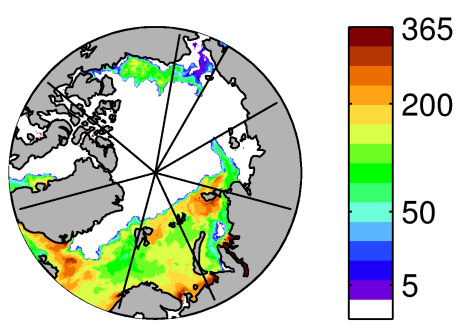

f) Days of silicate limitation

Fig. 5. Model results for year 1997: maximum DIN (a) and silicate (b) concentrations $\left(\mathrm{mmol} \mathrm{m}^{-3}\right)$; minimum concentration (mmol $\mathrm{m}^{-3}$ ) of DIN (c) and silicate (d); number of days that DIN (e) and silicate (f) concentrations are below their half-saturation level $\left(0.5 \mathrm{mmol} \mathrm{m}^{-3}\right.$ for nitrate and $1 \mathrm{mmol} \mathrm{m}^{-3}$ for silicate). Note non-linear scale.

\subsection{Primary production of the main ecological provinces}

The aim of this section is to assess, and where possible verify, total modelled productivity of the main ecological provinces: open water (deep and shelf), the marginal ice zone (deep and shelf) and ice. The area-integrated productivity of these provinces for years 1990-2005, as predicted by the model, is presented in Fig. 6, as well as the spatial distribution of annual primary production averaged over the water column for year 1997 in Fig. 7a. Results are compared with analysis of satellite-derived primary production by Pabi et al. (2008). Care must be exercised when undertaking this comparison for two reasons. First, satellite-derived primary production is itself an estimate based on various assumptions within a model that has been subject to limited verification for the Arctic. Second, problems associated with quantifying Chl- $a$ from remotely sensed ocean colour may be particularly acute in the Arctic relative to other parts of the World Ocean. These problems include signal contamination by sea-ice itself, by CDOM (coloured dissolved organic matter) in areas affected by riverine input, and by the frequent occurrence of Arctic fog in areas coincident with maximum Chl- $a$ concentrations (Perette et al., 2010), these being most pronounced at the onset of the ice-free period. In addition, the vertical distribution of Chl- $a$ in the AO is characterised by a strong sub-surface maximum (e.g. Hill and Cota, 2005). Exponential decline of Chl- $a$ below the UML utilised by (Pabi et al., 2008) would have introduced substantial errors in the depth integrated estimates.

\subsubsection{Ice ecological province}

Based upon historical in situ measurements and model results, an early estimate by Sakshaug (2004) calculated total Arctic Ocean primary production to be $329 \mathrm{Tg} \mathrm{Cyr}^{-1}$. Annual pan-Arctic satellite-derived primary production averaged over the period 1998-2006 was estimated to be $419 \mathrm{Tg} \mathrm{Cyr}^{-1}$ (Pabi et al., 2008), with a minimum of 


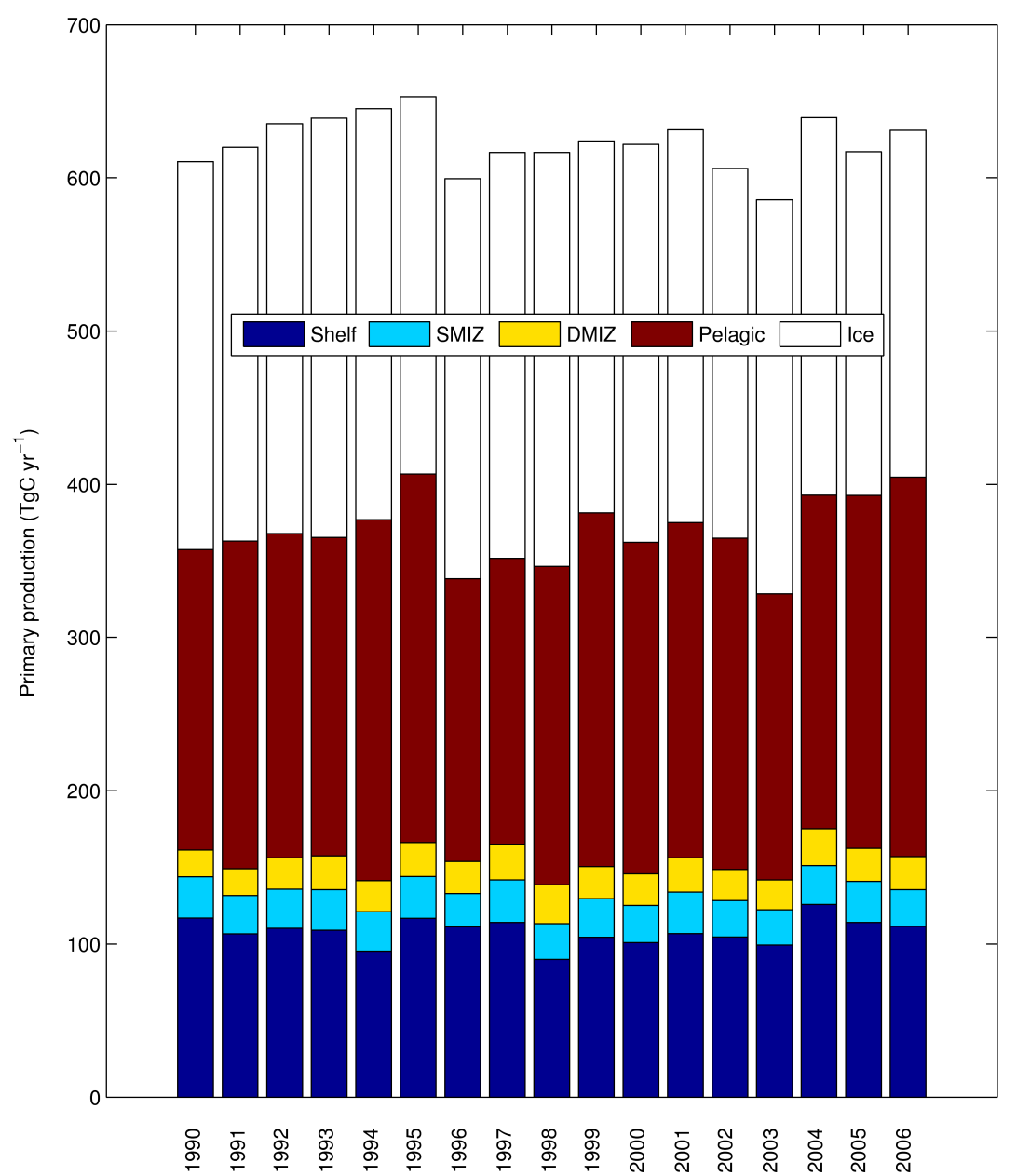

Fig. 6. Modelled annual primary production in the Arctic Ocean for each ecological province as defined in Sect. 2.5 during $1990-2006$ (cf.

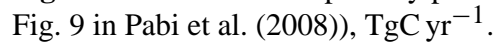

$375 \mathrm{Tg} \mathrm{Cyr}^{-1}$ in 1998 . However, as noted by Pabi et al. (2008), this is likely to be an underestimate because it does not take into account the contribution of the ice province. It is impossible to quantify primary production in the open leads and melt ponds from satellite data because of insufficient spatial resolution. Our model estimate of $626 \pm 20 \mathrm{Tg} \mathrm{C} \mathrm{yr}^{-1}$ is substantially higher than both these values. However $211 \pm 40 \mathrm{Tg} \mathrm{C} \mathrm{yr}^{-1}$ is produced in the ice province (Fig. 6). Is this relatively large contribution to total primary production by the ice province realistic? First of all, the $83 \%$ contribution of the ice province to the total $\mathrm{AO}$ area in the model is somewhat higher than a fraction of $71 \%$ based on observations. In addition, the modelled ice concentration during the productive period is probably about $10-15 \%$ lower than that observed (see Sect. 3.1). If it is assumed that light rather than nutrients sets an upper limit to annual primary production, the estimated production in the ice province may be as much as $20-30 \%$ too high. If an improved ice model is used, production in the ice province might decrease from 211 to about $150 \mathrm{Tg} \mathrm{C} \mathrm{yr}^{-1}$.
The ice ecological province is characterised by sea surface temperatures below $0^{\circ} \mathrm{C}$ and generally thick $3-5 \mathrm{~m}$ multiannual ice during the productive season (Carmack et al., 2006). However, numerous open water leads are present during the summer. These open and close under the influence of wind and currents such that ice cover is 10-20\% lower than that during winter (Sakshaug, 2004). Enhanced productivity occurs when leads stay open for a week or more, both within the leads themselves and in the surrounding water (Sakshaug, 2004). The model resolution is insufficient to explicitly represent leads, and enhanced primary production occurs in the model through the decrease in ice concentration and thus increase of PAR within grid cells.

The modelled annual primary production in the ice province varies between 5 and $20 \mathrm{~g} \mathrm{C} \mathrm{m}^{-2} \mathrm{yr}^{-1}$ (Fig. 7a). Both in the model and observations, the western domain of the ice province (northern parts of the Baffin, Beaufort and Chukchi sectors) is characterised by older and thicker ice with lower summer concentrations (Fig. 4c, d) than the eastern domain (northern parts of Greenland, Barents, 


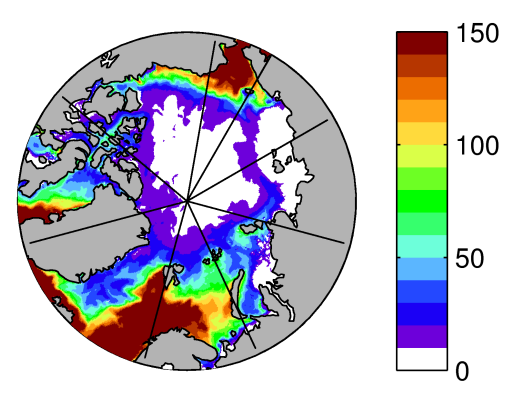

a) Annual primary production

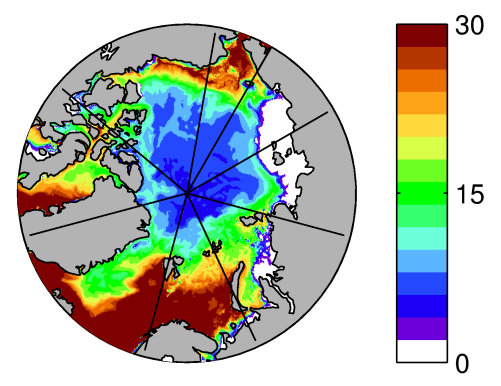

c) Integrated Chl-a

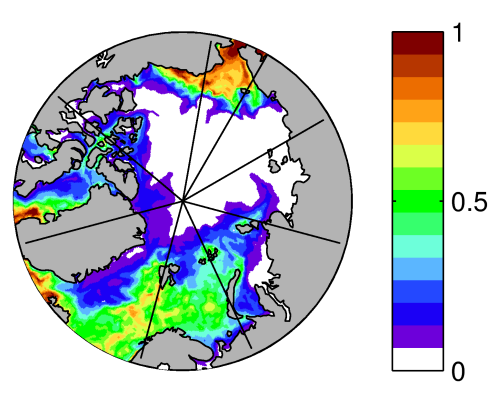

b) Surface Chl-a

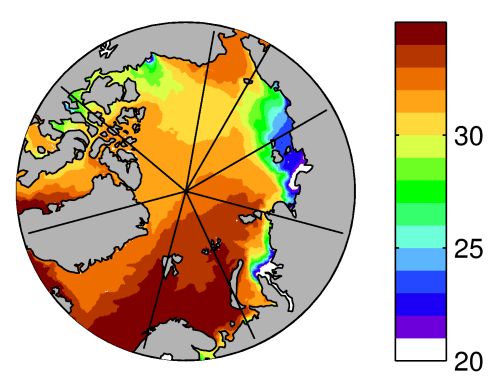

d) Surface salinity

Fig. 7. Model results for year 1997: (a) annual water column primary production in the Arctic Ocean $\left(\mathrm{g} \mathrm{C} \mathrm{m}^{-2} \mathrm{yr}^{-1}\right.$, note non-linear scale); (b) surface Chl- $a$ concentration $\left(\mathrm{mg} \mathrm{Chl} \mathrm{m}^{-3}\right)$; (c) water column integrated Chl- $a$ concentration $\left(\mathrm{mg} \mathrm{Chl} \mathrm{m}^{-2}\right)$; (d) surface salinity (PSU).

Laptev, Kara and East Siberian sectors). The anticipated consequences of these differences are a less favourable light regime and decreased vertical mixing in the western domain. Although the model shows differences in light level (Fig. 4a) the UML dynamics are similar throughout the whole ice province (Fig. 4b, c). However, the western domain is significantly influenced by the inflow of nutrient-rich Pacific seawater and is characterised by higher nutrient concentrations than the eastern domain where Atlantic inflow occurs (Fig. 5a, b). Thus, relative to the eastern domain, the modelled primary production in the western domain is limited by light to a higher degree and by nutrients to a lesser degree. Although these two factors provide opposite influences on the productivity that nearly cancel each other out, the impact of nutrients prevails and primary production in the western ice province is about a factor of 2 to 3 higher than in the eastern province.

Although early estimates of primary production in the deep Arctic Ocean suggested extremely low values of less than $1 \mathrm{~g} \mathrm{C} \mathrm{m}^{-2} \mathrm{yr}^{-1}$ (Apollonio, 1959; English, 1961), more recent studies have found that primary production in the icecovered Arctic Ocean is much higher (e.g. Gosselin et al., 1997; Sakshaug, 2004; Cota et al., 1996; Sherr and Sherr, 2003; Kirchman et al., 2009), and similar to our model estimates. Thus, we conclude that the model estimates of the primary production in these areas are consistent with obser- vations, and that the ice province is an important contributor to total Arctic primary production.

\subsubsection{Pelagic ecological province}

The pelagic ecological province is the second largest in the Arctic, comprising $11 \%$ of the total area of the AO in the model, as compared to $16 \%$ (Rayner et al., 2003) according to observations. This province is dominant in the Greenland sector, comprising about $80 \%$ of the area in both the model and observations. It also occupies about half of the Barents and Baffin sectors but is virtually non-existent in the Kara, Laptev and Siberian sectors where ice rarely retreats beyond the wide shelf break. In the model, it contributes

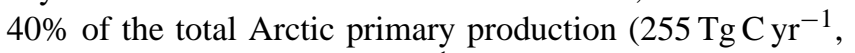
as compared to $150 \mathrm{Tg} \mathrm{Cyr}^{-1}$ estimated by Pabi et al., 2008). Area-normalised annual production in the model is $132 \pm 10 \mathrm{~g} \mathrm{C} \mathrm{m}^{-2} \mathrm{yr}^{-1}$, similar to the satellite-derived estimate of $127 \pm 8 \mathrm{~g} \mathrm{C} \mathrm{m}^{-2} \mathrm{yr}^{-1}$ by Pabi et al. (2008).

It is natural to separate the pelagic province into two distinctively different regimes, alpha and beta-type ecosystems. The majority of the pelagic province (e.g. Norwegian and South-western Barents Sea) is situated at the Atlantic inflow and manifests features of alpha-type ecosystems (Carmack and Wassmann, 2006). These areas are characterised by deep winter mixing that provides high nutrient 
supply to the photic zone and relatively weak stratification in summer. The combination of these two factors induces limitation of primary production by light rather than nutrients with the annual primary production in the model reaching $200 \pm 10 \mathrm{~g} \mathrm{C} \mathrm{m}^{-2} \mathrm{yr}^{-1}$. In the reminder of the pelagic province that is affected by the melting of sea ice the ecosystem regime is governed by a strong halocline, and therefore limited supply of nutrients. Modelled primary production in these areas is generally low $\left(40-70 \mathrm{~g} \mathrm{C} \mathrm{m}^{-2} \mathrm{yr}^{-1}\right.$, Fig. 7a).

\subsubsection{Shelf ecological province}

The shelf province comprises about $5 \%$ of the total AO area in the model and 7\% in the observations. Nevertheless, much as with shelf regions elsewhere, it is responsible for a disproportionately high fraction of primary production. In the model it contributes $17 \%$ of total production in the Arctic $\left(110 \mathrm{Tg} \mathrm{C} \mathrm{yr}^{-1}\right)$, as compared to $16-24 \%$ $\left(86 \pm 14 \mathrm{Tg} \mathrm{C} \mathrm{yr}^{-1}\right.$; Pabi et al. (2008)). Shelf areas are on average more productive $\left(120 \mathrm{~g} \mathrm{C} \mathrm{m}^{-2} \mathrm{yr}^{-1}\right)$ in the model than in the estimate of Pabi et al. (2008) $\left(95 \mathrm{~g} \mathrm{C} \mathrm{m}^{-2} \mathrm{yr}^{-1}\right)$.

Inflow shelves of the Chukchi and Barents Seas are major contributors to total primary production in the $\mathrm{AO}$ with model values exceeding $200 \mathrm{~g} \mathrm{C} \mathrm{m}^{-2} \mathrm{yr}^{-1}$. The interior shelves (Kara, Laptev, Siberian and Beaufort) receive the major fraction of discharges from Arctic rivers, and are characterised by a very stable stratification that imposes strong nutrient limitation. As a result, both in the model and in observations (Carmack et al., 2006), the interior shelves support primary production that is a factor of two to five lower than the inflow shelves of Chuckchi and Barents Seas, with values ranging from 20 to $70 \mathrm{~g} \mathrm{C} \mathrm{m}^{-2} \mathrm{yr}^{-1}$. The outflow shelves (Greenland and Canadian Arctic archipelago) support primary production rates in the model that are similar to those of the interior shelves, which is in agreement with the synthesis of Carmack et al. (2006).

\subsubsection{Shelf and deep marginal ice zones}

Satellite-derived primary production in the shelf marginal ice zone was estimated by Pabi et al. (2008) to be the second most important of all the ecological provinces, accounting for $28-33 \%$ of AO primary production $\left(132 \pm 6 \mathrm{Tg} \mathrm{C} \mathrm{yr}^{-1}\right)$ despite its relatively small spatial extent (16\% of the AO). On the basis of satellite-derived Chl- $a$, Pabi et al. (2008) estimated an areal productivity higher than in any other province, averaging $211 \pm 15 \mathrm{~g} \mathrm{C} \mathrm{m}^{-2} \mathrm{yr}^{-1}$ and reaching as high as $358-428 \mathrm{~g} \mathrm{C} \mathrm{m}^{-2} \mathrm{yr}^{-1}$ during the peak of the spring bloom. However, in the model the shelf marginal ice zone contributes only about $3 \%\left(21 \mathrm{TC} \mathrm{yr}^{-1}\right)$ of total AO primary production (Fig. 6). This low value is due in part to the area of this province being underestimated in the model (only about $6 \%$ of the total AO area), as well as to the areanormalised production being nearly factor of two lower than the Pabi et al. (2008) estimates $\left(125 \mathrm{~g} \mathrm{C} \mathrm{m}^{-2} \mathrm{yr}^{-1}\right)$. These factors require careful consideration given that, both qualitatively and quantitatively, there is a substantial discrepancy in satellite and model-based estimates of productivity of the MIZ.

The breaking of sea-ice floes and decreasing ice fraction through enhanced lateral melting of ice floes is known to be a principal mechanism affecting the sea ice evolution in the immediate vicinity $(O(1-10 \mathrm{~km}))$ of the sea ice edge (e.g. Squire, 1998). In contrast, the width of the MIZ (O(10$100 \mathrm{~km})$ ) is defined by a variety of processes. Some of these processes are not represented in global models due to the relatively coarse model resolution (e.g. inertial-internal waves), whereas the others are omitted by simplified model physics (e.g. tides, wave radiation stress and ice flow collisions). The details of the MIZ dynamics are outside the scope of this paper (the reader is directed to the comprehensive overviews in Wadhams, 1986 and Squire, 2007). These processes (unmodelled here) have a significant effect on sea ice and ocean dynamics in the MIZ. For example, by including wave radiation stress in a sea ice-ocean coupled model, Liu et al. (1993) simulated an enhanced Ekman pumping, upwelling and eddy formation in the near-ice edge zone. The unrepresentative MIZ dynamics in our simulation may be a result of the model's omission of these (and other) MIZ processes.

In part, the high MIZ productivity estimated by Pabi et al. (2008) is probably due to the contribution of so-called iceedge blooms (e.g. Perette et al., 2010). These are large bands of high Chl- $a$ that "follow" the retreating sea-ice in response to the opening up of the underlying ocean. It has been suggested that these ice-edge blooms may be responsible for up to half of the annual production on the Arctic shelves (Carmack et al., 2006), though the recent estimates of e.g. Perette et al. (2010) suggest that, in spite of a high Chl- $a$ signal, iceedge blooms may not be the most important mode of seasonal productivity.

The classical view of the dynamics of ice-edge blooms is as follows (Sakshaug and Skjoldal, 1989). As sea-ice retreats and melts, it introduces freshwater at the ocean surface that induces strong stratification. Solar irradiance also increases as ice cover shrinks and, with spring having arrived, provides conditions suitable for phytoplankton growth. From a lagrangian point of view, ice-edge blooms are generally understood to be short-lived phenomena that quickly strip out the nutrients from the shallow $(15-35 \mathrm{~m})$ surface mixed layer that is characteristic of seasonally ice-covered waters (Niebauer et al., 1981). If ice-edge blooms are to be considered from an eulerian point of view, however, each represents a long-lasting band of elevated chlorophyll concentration that follows the retreat of the sea-ice, leaving oligotrohic conditions in its wake. A recent satellite-based study by Perette et al. (2010) showed that ice edge blooms are a pan-Arctic phenomenon, occurring in all seasonally ice-covered areas of the AO. To what extent, then are ice edge Chl- $a$ blooms present in the model? 
Spatial distributions of 5-day averaged model ice concentrations, as well as surface concentrations of Chl- $a$, are shown in Fig. 8 for 10-16 April. Ice-edge blooms are clearly visible in the model in the Norwegian and Barents Seas. However, they penetrate far into the ice covered zone, as well as occurring in areas with ice concentration well above $10 \%$, thus their production is accounted in the ice rather than MIZ province. Further, ice edge blooms become less pronounced in July and August in the model despite the continuous ice retreat and enhanced values of Chl- $a$ and primary production that are observed in the model almost everywhere in ice covered areas. As was discussed in Sect. 3.1, model ice concentration in summer is underestimated thus promoting enhanced productivity in the ice province relative to that occurring in reality. Thus, instead of intense and fast moving ice-edge blooms, the main mode of productivity in the model is a slower and more prolonged period of elevated (albeit much less so) productivity that penetrates further into the areas of multi-annual ice. It seems that the area-integrated annual productivity is similar in both cases because it is the available nutrients, rather than light, that control the upper limit of algal growth. The two scenarios might nevertheless be substantially different in terms of resultant export production. One might expect rapid export from the euphotic zone to be associated with intense spring blooms where phytoplankton growth rate outstrips zooplankton grazing. In contrast, a more slow and prolonged light-limited growth in the presence of ice would allow a tighter coupling between phytoplankton and zooplankton, higher recycling and lower export. Our results therefore suggest that if further retreat of the Arctic sea-ice is to be accompanied by the reduced ice concentration in summer, ice edge blooms may disappear, or become less widely spread, than is seen today. However, further studies that address process-modelling of ice-edge blooms, and the physical factors controlling them, are essential for the future development of models of the AO ecosystem and its transition to a seasonally ice-fee ocean.

The annual primary production of the deep MIZ is the lowest of all Arctic provinces in both the estimates of Pabi et al. (2008) and in the model, $10-13 \%$ and $2.5 \%$ respectively. As for the shelf marginal ice zone, the area of this province is underestimated in the model thereby leading to a corresponding underestimate for primary production $\left(21 \mathrm{Tg} \mathrm{C} \mathrm{yr}^{-1}\right.$ against $47 \mathrm{Tg} \mathrm{C} \mathrm{yr}^{-1}$ in Pabi et al., 2008). The satelliet-derived estimates of area-normalised production in the deep MIZ Pabi et al. (2008) are similar to those of the pelagic province, but much lower than those in the shelf marginal ice zone. The shelf and deep MIZ do not exhibit substantially different productivity in the model. In general, the modelled shelves show low productivity compared to estimates of Pabi et al. (2008) (cf. Fig. 7 and 12 of Pabi et al., 2008), but are nevertheless in agreement with the synthesis of Carmack et al. (2006). It is not clear as to the extent to which unresolved shelf processes in the model, important for promoting high productivity, are responsible for this underestimate, or whether the data

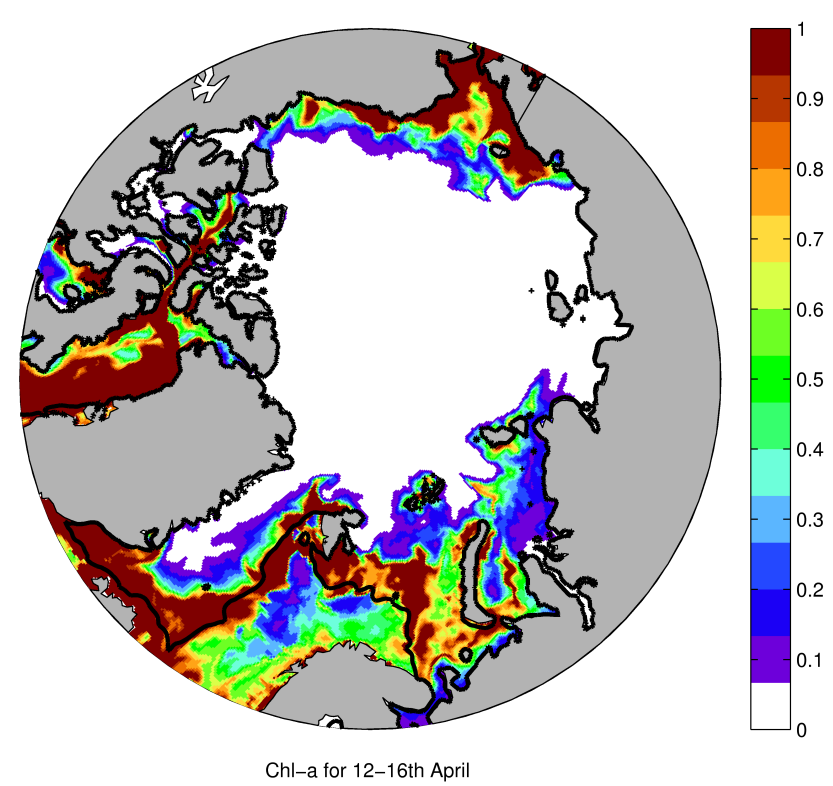

Fig. 8. Spatial distribution of the 5 day average surface concentration of Chl- $a\left(\mathrm{mg} \mathrm{Chl} \mathrm{m}^{-3}\right)$ for 13-16 April. Ice concentration of $50 \%$ is shown as a black line.

of Pabi et al. (2008) should be treated with caution for this area because they are potentially contaminated by riverine input of CDOM (see also discussion of the Siberian sectors in the next section).

\subsection{Regional patterns of primary production and ecosystem dynamics}

The aim of this section is to asses the spatial variability of primary production and ecosystem characteristics in the AO sector by sector (Sect. 2.5), and to compare with in-situ data where possible. Analysis is also undertaken of the correlation between primary production (Fig. 7a) and physical factors such as the number of days of open water (Fig. 3a), annual mean short-wave radiation (Fig. 4a), surface salinity (Fig. 7d) and the maximum depth of mixing (Fig. 4c).

Many in-situ studies have observed a subsurface Chl- $a$ maximum as a perennial feature of AO ecosystems (e.g. Hill and Cota, 2005). The characteristics of the modelled subsurface Chl- $a$, calculated for period of May-September 2007, are depicted in Fig. 9, showing the duration of the subsurface maximum in days (Fig. 9a), the averaged value of the subsurface maximum for May-September (Fig. 9b); average strength (Fig. 9c; calculated as the ratio of the subsurface maximum relative to the surface value), and average depth (Fig. 9d). The contribution of the subsurface Chl- $a$ maximum to total water column integrated Chl- $a$ and primary production is shown in Fig. 9e, f. Here the "subsurface maximum" contribution is that, in Chl- $a$ and productivity terms, occurring below the UML depth. 


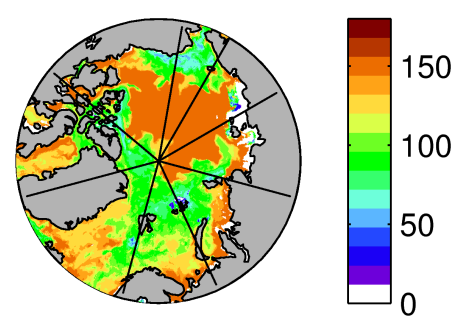

a) Duration (days)

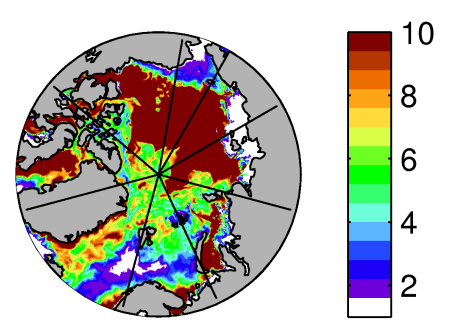

c) Strength

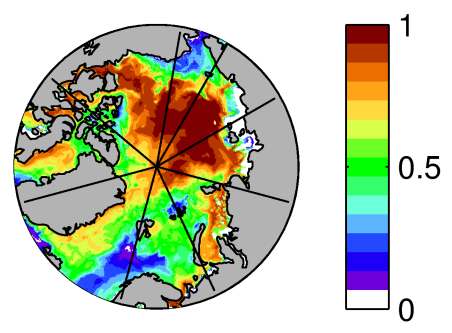

e) Subsurf fraction of PP

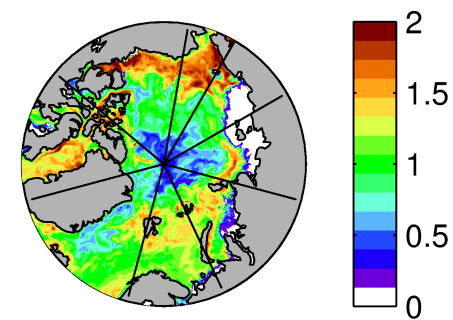

b) value $(\mathrm{mgChl} / \mathrm{m} 3)$

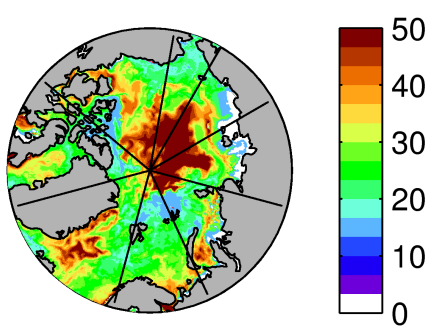

d) Depth (m)

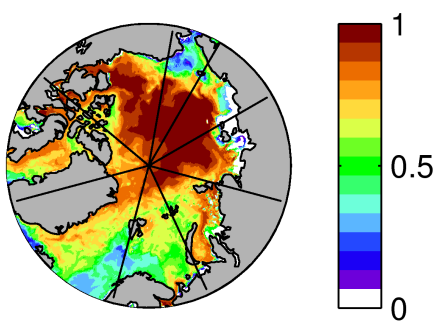

f) Subsurf fraction of $\mathrm{Chl}$

Fig. 9. Duration of the subsurface Chl- $a$ maximum in days (a), average value of the Chl- $a$ maximum in $\mathrm{mg} \mathrm{Chl} \mathrm{m}^{-3}$ (b), averaged strength (calculated as a ratio of subsurface maximum to the surface value), (c), and averaged depth in $\mathrm{m}$ (d); contribution of the subsurface Chl- $a$ maximum to water column integrated primary production (e) and Chl- $a$ (f). The contribution of the subsurface maximum to water column characteristics is calculated as a ratio of the integral value below the UML depth to the total water column integral value.

\subsubsection{Chukchi sector}

The physical and biological regimes of the seasonally icecovered Chikchi sector are strongly influenced by the northward flow of water, driven by sea-level difference, from the Bering Strait (Woodgate et al., 2005). Advection of nutrientrich waters supports a highly productive regime on the edge of the otherwise largely oligotrohic Arctic Ocean (Hill and Cota, 2005). Spatial distribution of primary production in the Chukchi sector is controlled by ice extent in summer, as well as key hydrographic features (primarily defined by varying salinity; Grebmeir et al., 2006). Of particular importance for primary production are nutrient-rich Anadyr Water and Alaska Coastal Water flowing northward on the eastern side of the Chuckchi Sea, and the fresh, nutrient-depleted southeastward flow through the Siberian coastal current (Grebmeir et al., 2006).
Annual primary production is observed to be highest in the Arctic on the nutrient-rich shelf of the Chukchi Sea (Grebmeir et al., 2006, and references therein), with values of 70 $80 \mathrm{~g} \mathrm{C} \mathrm{m}^{-2} \mathrm{yr}^{-1}$ (excluding the intense localised plumes that occur in the southern part of the Chukchi Sea where production can reach values of $400 \mathrm{~g} \mathrm{C} \mathrm{m}^{-2} \mathrm{yr}^{-1}$ ). Lower values of primary production of $20-70 \mathrm{~g} \mathrm{C} \mathrm{m}^{-2} \mathrm{yr}^{-1}$ are observed in the northern Chukchi Sea and along the Alaskan and Siberian coast. Modelled primary production shows a similar pattern (Fig. 7a), with maximum values of up to $200 \mathrm{~g} \mathrm{C} \mathrm{m}^{-2} \mathrm{yr}^{-1}$ in the southern part of the Chukchi sea and $20-80 \mathrm{~g} \mathrm{C} \mathrm{m}^{-2} \mathrm{yr}^{-1}$ outside of the southern areas affected by the Bering inflow. Maximum diatom productivity occurs in the silicic acid-rich Chukchi Sea, where this group contributes about half of the total production. The subsurface Chl- $a$ maximum is not strong in this area (Fig. 9b) because of the high surface concentrations of nutrients in the southern part of the Chukchi sector, and does not contribute a significant fraction of primary production or depth-integrated Chl- $a$ (Fig. 9e, f). 
The western part of the Chukchi Sea, adjacent to the Siberian coast, is a poorly sampled region. Modelled primary production in this area is heavily controlled by ice extent, and by the low nutrient concentrations in the Siberian coastal current driven by freshwater arriving from the Kolyma river. The modelled nutrient distributions along this coastline are subject to relaxation towards a nutrient climatology, and therefore should be treated with caution because of potential errors in this climatology.

Primary production over the shelf part of the Chukchi sector is variable but closely follows the spatial distribution of surface salinity (Fig. 7d). This is unsurprising because the factors that control both nutrient supply and salinity distributions in this region are the same, e.g. the inflow of high salinity and nutrient-rich water through the Bering strait, and the influence of the fresher, low-nutrient Siberian coastal current.

A strong subsurface maximum is a dominant feature of the productivity regime beyond the shelf break where nutrients, rather than light (Fig. 5c), limit primary production. Although the value of the subsurface maximum decreases northwards, its strength increases (reaching a maximum at about $82^{\circ} \mathrm{N}$ ), driven by an increase in nutrient limitation. The maximum deepens progressively northwards, reaching values typically more than a factor of 5 higher than that of surface Chl- $a$. As much as $80-90 \%$ of primary production in this area is sustained in the subsurface chlorophyll maximum (Fig. 9e). Similar findings were made by Hill and Cota (2005) in the summer of 2002 on the shelf break of the Chukchi and Eastern Beaufort seas.

\subsubsection{Beaufort sector}

The margins of the Beaufort Sea are relatively narrow compared to the Siberian shelves. Observed primary production is $30-70 \mathrm{~g} \mathrm{C} \mathrm{m}^{-2} \mathrm{yr}^{-1}$ (Carmack et al., 2006; Hill and Cota, 2005), similar to that obtained in the model (Fig. 7a). As was the case for the shelves of the Siberian sectors, the model indicates that it is nutrient limitation (Fig. 5c) rather than light that sets an upper limit to annual primary production in the UML. Similar to observations, model results show annual production of $70-90 \mathrm{~g} \mathrm{C} \mathrm{m}^{-2} \mathrm{yr}^{-1}$ on the shelf and 20 $30 \mathrm{~g} \mathrm{C} \mathrm{m}^{-2} \mathrm{yr}^{-1}$ on the edge of the basin (Fig. 7a). A surface nitrate minimum occurs between July and August in the model, with values below the phytoplankton half-saturation levels (Fig. 5c). A strong sub-surface maximum of Chl- $a$ (Fig. 9a, b) is formed from July until September, at a depth of about 20 to $40 \mathrm{~m}$ (Fig. 9d). In the model, nutrient limitation on the shelves of the Beaufort sector increases from west to east with the distance from the Bering inflow (Fig. 5c), accompanied by decreasing annual production (Fig. 7a) and strength of the subsurface Chl- $a$ maximum (Fig. 9c).

The subsurface $\mathrm{Chl}$ maximum in the Beaufort sector is strongest in the eastern part. Light limitation, caused by the presence of dense multi-annual ice (Fig. 3c) and deeper mixed layers (Fig. 4b), prevents the development of a strong subsurface chlorophyll maximum toward the Canadian Archipelago. 70-90\% of primary production in this area occurs within the UML, which typically extends to depths of 20-30 m (Fig. 9e).

Primary production in the Beaufort sector (Fig. 7a) generally follows the spatial distribution of two physical factors, surface salinity (Fig. 7d) in the shelf and southern most part of the deep basin (reflecting levels of nutrient limitation) and summer short-wave radiation (Fig. 4a) in the northern part of the deep basin (reflecting levels of light limitation).

\subsubsection{Baffin sector}

The Baffin sector includes three distinct areas: Baffin Bay, a substantial part of the Canadian Archipelago, and the deep Arctic basin covered by multi-annual ice. The Canadian Archipelago is a large and complex AO shelf with narrow channels and interconnecting basins. Its complex topography, shelf-exchange processes and highly variable ice cover determine the physical regime of this region (Michel et al., 2006). Modelled primary production in the Canadian Archipelago (Fig. 7a) is low, $20-70 \mathrm{~g} \mathrm{C} \mathrm{m}^{-2} \mathrm{yr}^{-1}$, in good agreement with observations (Carmack et al., 2006) in spite of the resolution of the underlying physical model being insufficent to describe intricacies of the shelf dynamics and water mass exchanges through the multiple narrow channels.

Baffin Bay, which is seasonally covered by ice, is substantially more productive, with production rates showing a marked correlation with the depth of winter mixing (Fig. 4c). Deep mixing in the southern and western areas supplies high nutrients that sustain production of $100-140 \mathrm{~g} \mathrm{C} \mathrm{m}^{-2} \mathrm{yr}^{-1}$ (Fig. 7a). In contrast, the northern part of the Bay, which is influenced to a greater extent by ice, is mixed only down to $40-60 \mathrm{~m}$ in winter (Fig. 4c) leading to primary production of only $30-60 \mathrm{~g} \mathrm{C} \mathrm{m}^{-2} \mathrm{yr}^{-1}$ which is limited by nutrients (Fig. 7a).

\subsubsection{Greenland sector}

The Greenland sector of the AO has three distinct geographical areas, north, north-west and south-east, each of which has a different relationship with sea-ice. The northern part of the sector is covered by multi-annual ice (Fig. 3a), with no days of open water and negligible primary production. This lack of biological activity is paralleled in the model, so this area is excluded from further analysis. In contrast, the north-west area is affected by seasonal ice cover, while the south-east area is permanently ice-free.

Primary production in the north-west area is typically low (40-70 $\mathrm{g} \mathrm{C} \mathrm{m}^{-2} \mathrm{yr}^{-1}$ ) in both observations (Sakshaug, 2004) and the model (Fig. 7a). Sakshaug (2004) suggested that phytoplankton dynamics in areas affected by melting of the ice resemble those of the shelf seas. Model results suggest that, due to a substantially weaker stratification in summer, 
the ecosystem regime is qualitatively different to that of the shelf regime and that primary production is limited by light rather than nutrients (Fig. 5c) during most of the productive period.

The south-east part of the Greenland sea is permanently ice-free and is a typical $\alpha$-type ocean. Atlantic inflow permits deep convection to penetrate down to 400-500 m (Fig. 4c), supplying large amounts of nutrients. Primary production in this area reaches $100-150 \mathrm{~g} \mathrm{C} \mathrm{m}^{-2} \mathrm{yr}^{-1}$ both in the model (Fig. 7a) and observations (Carmack et al., 2006). A subsurface Chl- $a$ maximum does not occur in this area (Fig. 9c) because of the deep (50-70 m) UML in summer (Fig. 4b). Model depth-integrated Chl- $a$ is the highest found across the entire Arctic ocean (Fig. 9c). The south-east part of the Greenland sector is also one of the two most productive areas of the AO, the second being the Chukchi Sea at the Pacific inflow. Unlike the Chukchi sea, however, silicate concentration is substantially lower in this area, exhausted to below the half-saturation level after the spring bloom. As a result, primary production in the model mostly consists of small, non-diatom phytoplankton which are considerably more susceptible to grazing by zooplankton than the Pacific, mostly diatom, phytoplankton community.

Regarding the Greenland sector in general, the spatial distribution of primary production closely follows both the maximum depth of winter mixing (Fig. 4c) and number of days of open water (Fig. 3c). This latter correlation with open water does not, however, imply that light is necessarily the main limiting factor in this sector. Rather, it can be explained by the fact that ice is not formed in areas affected by the North Atlantic inflow which have typical deep winter mixing that supplies high nutrients.

\subsubsection{Barents sector}

Approximately $14 \%$ of the total area of the AO is accounted for by the Barents sector, with primary production in the model for this area contributing about $20 \%$ to the total for the $\mathrm{AO}$. In terms of the area-normalized production rate, it is one of the two most productive sectors of the AO. Continental shelves constitute approximately $44 \%$ of its area. The model annual primary production of $118{\mathrm{Tg} \mathrm{C} \mathrm{yr}^{-1}}^{-1}\left(92 \mathrm{Tg} \mathrm{C} \mathrm{yr}^{-1}\right.$ of the contribution of the area covered by the multi-annual ice is excluded) is in good agreement with the ice-free satellitederived estimate of Pabi et al. (2008) of about $80{\mathrm{Tg} \mathrm{C} \mathrm{yr}^{-1}}^{-1}$ (for year 1998).

The Polar Front separates the two main water masses of the Barents sea, namely the Arctic water in the north-east and Atlantic water in the south-west. These water masses exhibit distinctly different ecosystem dynamics and rates of primary production (Fig. 7a) such that they can be considered as $\alpha$ (Atlantic water mass) and $\beta$ (Arctic water mass) types of ecosystems (see Sect. 2.6).

The Atlantic surface flow causes the south-west part of the Barents sea to be permanently ice-free (Fig. 3a). Ecosys- tem dynamics and primary production in this area are similar to those of the Norwegian sea (Carmack et al., 2006). Deep winter mixing in the Atlantic part of the Barents sector both in the model (Fig. 4c) and observations (e.g. Olsen et al., 2003) reaches the bottom over the shelf area $(<250 \mathrm{~m})$ and provides a significant source of nutrients. Nitrate is not decreased below half-saturation levels during the summer in these areas (Fig. 5c), which facilitates a long-lasting bloom with annually averaged values of primary production reaching $130-170 \mathrm{~g} \mathrm{C} \mathrm{m}^{-2} \mathrm{yr}^{-1}$.

The seasonally ice-covered Arctic part of the Barents sector has much shallower winter mixing (Fig. 4c) due to a more stable stratification influenced by the sea-ice cover. This lack of winter mixing prevents entrainment of nutrients into the surface layer thereby causing substantially lower levels of productivity of $40-80 \mathrm{~g} \mathrm{C} \mathrm{m}^{-2} \mathrm{yr}^{-1}$ (Fig. 7a). Nutrient limitation in this area is not, however, as severe as on the Siberian shelves and the shelves of the Beaufort sector (Fig. 5c). A similar distribution of primary production in the Barents sea was obtained in the modelling study of Wassmann et al. (2006, Fig. 5a), with values varying between 40 and $170 \mathrm{~g} \mathrm{C} \mathrm{m}^{-2} \mathrm{yr}^{-1}$. A subsurface Chl- $a$ maximum is usually formed in the north-east (Arctic) part of the Barents sector, although it is not as strong as in the Chukchi sector or on the shelf break of the Siberian sectors (Fig. 9c). The subsurface maximum fuels about $50 \%$ of annual primary production in this area (Fig. 9d).

\subsubsection{Kara, Laptev and Siberian sectors}

The Kara, Laptev and Siberian shelves are broad and receive the majority of the river discharge entering the Arctic Ocean. They support primary production which is 5-10 times lower than that of the inflow shelves of the Bering and Barents Seas (Carmack et al., 2006). Production is about $20-30 \mathrm{~g} \mathrm{C} \mathrm{m}^{-2} \mathrm{yr}^{-1}$ in both observations and model, reaching $50-60 \mathrm{~g} \mathrm{C} \mathrm{m}^{-2} \mathrm{yr}^{-1}$ at the shelf break of the Kara Sea and Laptev Seas in the model (Fig. 7a), a sector least affected by the riverine input. Substantially higher primary production on the Siberian shelf was estimated by Pabi et al. (2008) on the basis of satellite-derived Chl- $a$. However, Vetrov (2008) presented a comparison of satellite (MODIS) and in-situ Chl$a$ values in Kara and Laptev seas and showed that the former can be up to factor of two to ten higher due to contamination by coloured dissolved organic matter. Calculated annual primary production based on Chl- $a$ values corrected for this bias did not exceed $50 \mathrm{~g} \mathrm{C} \mathrm{m}^{-2} \mathrm{yr}^{-1}$ for the majority of the Laptev sea shelf, and $100 \mathrm{~g} \mathrm{C} \mathrm{m}^{-2} \mathrm{yr}^{-1}$ on the shelf of the Kara sea (Vetrov, 2008). Thus, even factoring in these observational corrections, the model tends to underestimate productivity of the Siberian shelves.

Model results indicate that some of the southern most parts of these areas stay ice-free for up to 150 days and it is nutrients (in particular nitrate), rather than light, that limit primary production (Fig. 5c) during most of the productive 
season. This nutrient limitation is driven by the stable stratification that results from a significant discharge of fresh water from rivers (Carmack and Wassmann, 2006). The upper mixed layer in the model does not penetrate below $20 \mathrm{~m}$ (Fig. 4b, c) over most of the Siberian shelves. Nutrient limitation increases from the Kara, through the Laptev, and into the East Siberian Sea with the increasing stratification. Annual short-wave radiation decreases further north towards the shelf break, mostly due to increased ice cover, and light limitation plays a more significant role. Nutrients nevertheless become depleted throughout the Siberian shelves during the summer both in observations (Nitishinsky et al., 2007) and the model.

Depth integrated Chl- $a$ (Fig. 7c) has a pronounced maximum along the shelf-break, corresponding to the maximum in primary production (Fig. 7a) which is not visible in surface Chl- $a$ (Fig. 9b). The sub-surface Chl- $a$ maximum (Fig. 9c) persisted throughout the ice-free period and sustained 50$80 \%$ of water column primary production (Fig. 9d).

For all three sectors in general, the spatial distribution of primary production correlates both with surface salinity (Fig. 7d) on the shelf and with summer ice concentration (Fig. 3c) in the deep basin. Neither feature is surprising since shelves exhibit pronounced shortages of nutrients for plankton growth caused by the stable stratification resulting from riverine input of the fresh water. The eastern most part of the area adjacent to the Chukchi sector has higher nutrient concentrations due to the Bering inflow, also reflected in the surface salinity field. The northern part of the sector covered by multi-annual ice is limited by light to a greater degree, with primary production showing a good correlation with the spatial distribution of ice concentration.

\subsection{Physical factors defining AO primary production}

Results presented in the previous section indicate that the Arctic Ocean is an area where physical factors impose a strong control on plankton productivity. The presence of sea ice controls both vertical stratification and light penetration into the ocean. Given that the ecosystem is co-limed by light and nutrients, this makes it difficult to pinpoint which particular physical factor(s) have the greatest impact on the basinwide distribution of productivity. In order to overcome the complexity of the interplay between the mechanisms controlling AO productivity described above in Sects. 3.1-3.4 we employ a multiple regression analysis using the following physical parameters that we have identified as potential predictors for annual mean primary production: (i) maximum depth of vertical mixing, as the main mechanism of nutrient supply; (ii) short-wave radiation at the ocean surface, or averaged over the UML depth, and summer-time averaged UML depth as factors controlling light limitation; (iii) surface salinity as an indicator of the riverine input that induces strong vertical stratification and nutrient limitation; salinity aiso acts as an indicator of the horizontal transport of nutri- ents, such as in the vicinity of the Bering strait, where horizontal advection is an important controlling mechanism; (iv) ice concentration, as a major factor controlling light penetration and UML dynamics; (v) SST, as a field reflecting the presence of ice, as well as the main features of the physical circulation such as, for instance, Atlantic inflow.

In order to evaluate the quantitative significance of these factors, we fitted a multiple linear regression model for mean annual primary production (PP) as a function of all model output fields $\left(X_{i}\right)$ listed above:

$\mathrm{PP}=a+\sum_{i=1}^{n} b_{i} X_{i}$

The resulting correlation coefficient between primary production from the regression model and that of the full model was very high (0.91). Furthermore, the mean summer time (April-September) short wave radiation (SW; Fig. 4a) and the maximum depth of winter mixing $\left(H_{\max }\right.$; Fig. $\left.4 \mathrm{c}\right)$ together described more than $80 \%$ of the spatial variability in primary production (correlation coefficient of 0.88 ). Considering the high contribution of these two factors, we limited our regression model to the form

$\mathrm{PP}=a+b \mathrm{SW}+c H_{\max }$

where $a=-1.36 \mathrm{~g} \mathrm{C} \mathrm{m}^{-2} \mathrm{yr}^{-1}, b=1.35 \mathrm{~g} \mathrm{C} \mathrm{m}^{-3} \mathrm{yr}^{-1} \mathrm{~W}$, $c=0.18 \mathrm{~g} \mathrm{C} \mathrm{m}^{-3} \mathrm{yr}^{-1}$.

The spatial distribution of primary production from the regression model (Fig. 10b) shows good agreement with that predicted by the full ecosystem model (Fig. 10a). The maximum penetration of winter mixing largely determines the amount of nutrients available for primary production at the beginning of spring (e.g. Popova et al., 2006a,b). The main feature that this field captures in the AO is the basin-scale separation between alpha and beta waters. Additionally, since areas affected by melting of ice do not show deep convective mixing, the depth of winter mixing also acts as a proxy for the ice regime. Meanwhile, the light regime is best described by the summertime (April-September) short-wave radiation at the ocean surface (i.e. that which reaches a model grid cell through ice cover) since this takes into account not only the atmospheric state but also attenuation by sea-ice. As might be expected, the main errors in the regression model occur in regions that are affected by horizontal advection: the southern part of the Chukchi sector and Atlantic inflow in the Greenland sector. These regions have an additional advective source of nutrients for primary production that is not accounted for in the regression parameters. In the southern part of the Chukchi sector, the primary production from the regression model is underestimated by $30-40 \%$. At the Atlantic inflow, the regression model somewhat distorts the pattern of high productivity that features south-west of Svalbard. We can speculate that the correlation coefficient could be improved if an advective pseudo-tracer constrained by the salinity field was introduced as a tracer of the Pacific and Atlantic inflows. 


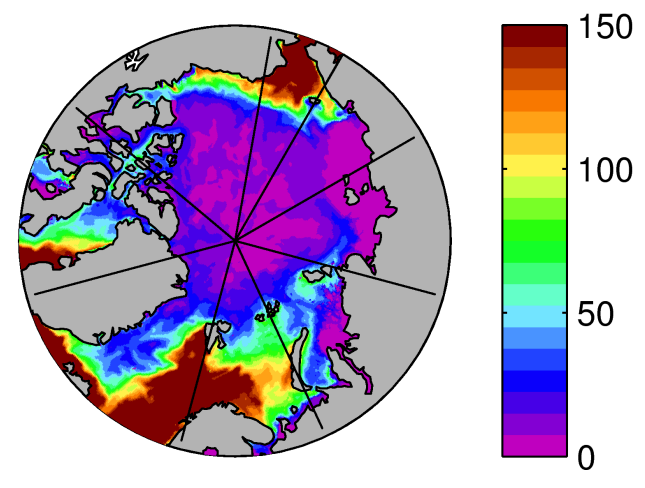

a) Production (MEDUSA)

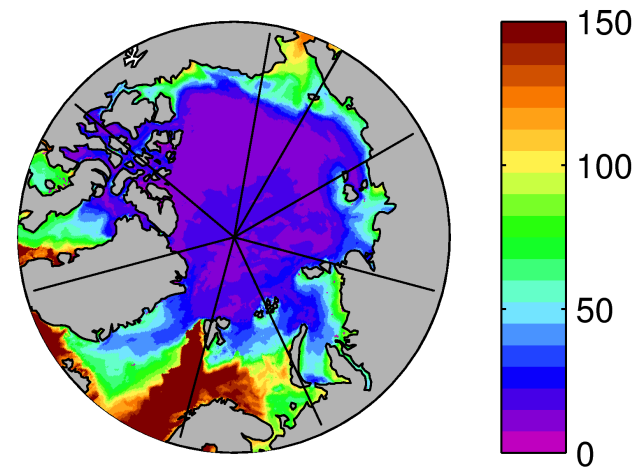

b) Production (regr model)

Fig. 10. Primary production $\left(\mathrm{g} \mathrm{C} \mathrm{m}^{-2} \mathrm{yr}^{-1}\right)$ obtained from (a) the MEDUSA ecosystem model, (b) the multiple linear regression model with summer short wave radiation and maximum winter mixing as predictors.

Can our simple regression model describe the inter-annual variability in primary production? And, to a first approximation, can primary production be estimated from the output of the physics-only model or observations without recourse to a computationally-expensive ecosystem model such as that used in this study? We applied regression coefficients $a, b$, $c$ obtained for year 1997 for the SW and $H_{\max }$ fields from year 1988-2006 to calculate total AO primary production (Fig. 11). Results indicate that the regression model shows the same interannual variations (correlation coefficient 74\%).

\section{Discussion}

In part due to the decline in Arctic sea-ice itself (Deser et al., 2000), climate warming appears to be occurring at a disproportionately high rate in the Arctic, leading to ice retreat

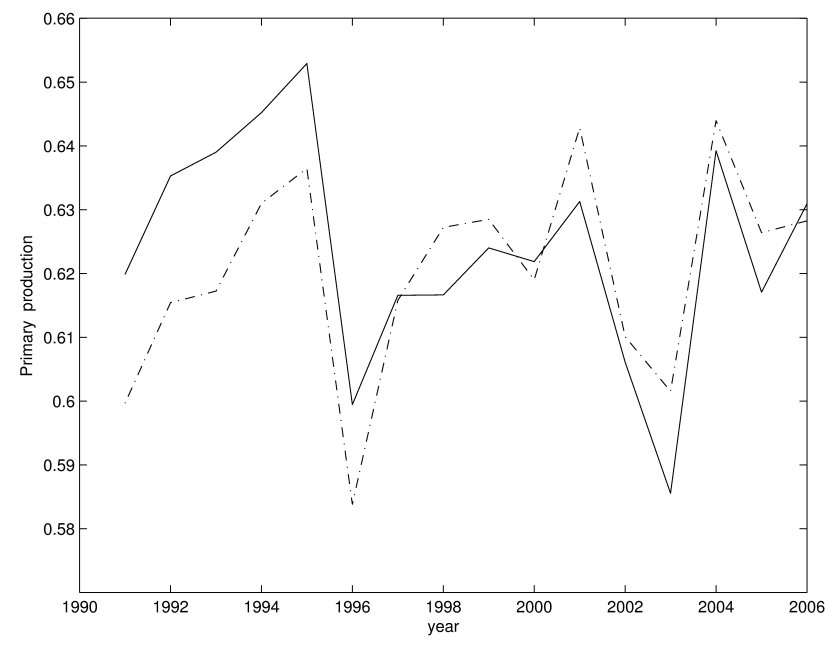

Fig. 11. Interannual variability of the total AO primary production $\left(\mathrm{Tg} \mathrm{C} \mathrm{yr}^{-1}\right.$ ) obtained from the MEDUSA ecosystem model (solid line) and multiple linear regression model with summer short wave radiation and maximum winter mixing as predictors (dashed line).

along with possible changes in water column stratification (e.g. ACIA, 2004). These changes will in turn impact on Arctic Ocean ecosystems and associated biogeochemistry, altering primary production and, potentially, the uptake of $\mathrm{CO}_{2}$ by Arctic Ocean surface waters (Bates and Mathis, 2009).

The key to predicting future changes in Arctic productivity and related carbon biogeochemistry is therefore an understanding of the link between sea-ice retreat and the factors that regulate phytoplankton growth. In spring, productivity is likely to be limited by light due to the presence of ice exacerbated by the low solar elevation, such that high rates occur in areas associated with ice retreat and open water leads (e.g. Hill and Cota, 2005). Increases in productivity might therefore be expected if sea ice thickness and concentration are diminished due to elevated solar energy penetrating the ocean. In reality, however, the link between ice retreat and primary production is not so straightforward.

First, ice retreat affects not only irradiance levels, but also other fundamental properties shaping ecosystem functioning such as vertical stratification, circulation and the water mass structure. The factors controlling density structure are unique in the Arctic because of the formation of a permanent halocline (e.g. Aagard et al., 1981). This occurs when cold, saline water is formed during freezing of sea-ice and sinks to the bottom of the continental shelf from where it is laterally advected into the deep Arctic basin. The density of the halocline causes it to settle at a depth of $\sim 150 \mathrm{~m}$, forming a barrier that essentially "caps" the deeper water from that at the surface (Smith and Niebauer, 1993). The strength of this halocline limits the depth of the winter mixing and thereby restricts one of the main mechanisms of nutrient supply to surface waters in the AO. Second, spring melting of sea-ice, supplemented by river discharge of snowmelt on 
land, induces a strong and shallow $(15-30 \mathrm{~m})$ seasonal halocline where the subsurface Chl- $a$ maximum is formed (e.g. Hill and Cota, 2005; Carmack et al., 2006).

So, although limitation by light may control the timing and magnitude of the spring phytoplankton bloom, it may instead be the availability of nutrients that sets the limits to annual primary production, at least the "new" fraction (Dugdale and Goering, 1967; Carmack et al., 2006). Consequently, a more ice-free Arctic may naively be anticipated to exhibit increased productivity on grounds of elevated energy availability, but may actually respond quite differently on grounds of material availability. Ice retreat not only alters the irradiance field controlling the phytoplankton growth, but also potentially causes changes to the water column stratification and shifts in AO circulation. It can be speculated that if the seasonal ice edge routinely retreats past the shelf break it would intensify shelf-break upwelling of warm and nutrient rich water (Carmack and Chapman, 2003). Earlier break-up and later freeze-up of the ice would provide a longer exposure of the water column to the negative buoyancy forcing and impact of storm events (Yang et al., 2004) thus increasing the maximum depth of winter mixing (Carmack et al., 2006) and supplying higher nutrients. Rainville and Woodgate (2009) showed that retreat of the ice will lead to significantly increased internal wave generation over the shelfs and possibly deep ocean, dramatically increasing upper-layer mixing. However all the above factors can be counterbalanced by the projected increase in riverine input (Wu et al., 2005) which, potentially, may lead to the future stabilisation of stratification.

To explore the underlying factors controlling present-day Arctic primary production, our study has examined the relative roles of light and nutrients as controls of biological activity in the Arctic Ocean using an intermediate complexity plankton ecosystem model embedded within a high resolution general circulation model. Our results show that, in spite of relatively low surface short wave radiation due to the low solar elevation and frequent occurrence of Arctic fog, a very shallow and stable summer time UML of 10-20 m provides a light regime favorable for phytoplankton growth (Sect. 3.1) even in the presence of the fractional ice cover. The ice province (defined as the area with ice concentration in excess of 10\%) contributed 30-45\% of total Arctic primary production in the model. Nitrate concentration fell below its half-saturation value in the UML during the productive season over the majority of the AO, leading to limitation by nutrients (Sect. 3.2). The only exceptions, where nitrate concentrations did not fall below the half-saturation level by the end of the productive season, were found in areas substantially affected by the Pacific and Atlantic inflow (Fig. 5c, e). These results show that it is lack of nutrients, rather than light, that sets an upper limit on annual primary production in the UML.

A notable feature in the model is the presence of a deep chlorophyll maximum (DCM) throughout much of the Arc- tic Ocean (Fig. 9). A number of observational (e.g. Hill and Cota, 2005), conceptual (e.g. Carmack et al., 2006) and modelling (Wassmann et al., 2006) studies have indicated that much of the chlorophyll present in AO ecosystems may occur in subsurface maxima that follow the fast, intense and shortlived ice-edge blooms that strip nutrients out of the UML. In our model, the DCM accounted for approximately $46 \%$ of total Arctic primary production, a remarkable fraction. If areas significantly affected by Pacific and Atlantic inflow (somewhat arbitrarily defined as areas with maximum DIN concentrations in excess of $10 \mathrm{mmol} \mathrm{N} \mathrm{m}^{-3}$, Fig. $5 \mathrm{a}, \sim 25 \%$ of the total $\mathrm{AO}$ area) are excluded, the contribution of the DCM to total production increases to $68 \%$. Comparison of the modelled with observational DCM in the Chukchi and Beaufort sectors (e.g. Hill and Cota, 2005) shows robustness of the model results in these areas, although pan-Arctic evaluation of model performance with respect to the distribution of the DCM and its contribution to AO production is not currently possible because of lack of data. Even in areas affected by Pacific and Atlantic inflow, where nutrients are present in relatively high concentrations, the DCM accounted for 30-40\% of water column integrated chlorophyll in the model (Fig. 9e, f). It is difficult to separate the limiting effects of light and nutrients in the DCM because by their very nature. DCMs occur at the juncture where light penetrating from above meets the upward flux of nutrients from below (e.g. Banse, 1987). An increase in light intensity, for example associated with reduced ice concentration, might therefore be expected to lead to an intensification and deepening of the DCM and thereby an increase in primary production, provided stratification remains unchanged. These changes would not, however be detectable in remotely sensed Chl- $a$ because they occur well below the ocean surface. Furthermore, the dominant role played by the DCM in total Arctic primary production limits the applicability of satellite-derived primary production algorithms (e.g. Pabi et al., 2008), since they are based on the near-surface Chl- $a$ values. Overall, much of the primary productivity in the $\mathrm{AO}$ occurs in the DCM and it is not clear how the balance between light and nutrient limitation will be altered in response to changing sea-ice.

It is therefore possible to speculate that a further retreat of the ice, for example in response to climate forcing, should not lead to increased UML productivity unless accompanied by physical changes leading to weakening of the stratification. An analysis of recent trends in satellite-derived primary production in the Arctic by Arrigo et al. (2008) indicated that the Siberian sector experienced the largest increase in 2007, with an annual rate that was more than three-fold higher than in 1998-2006. This finding poses an intriguing question as to the mechanisms that sustained such an increase. For example, as described by (Carmack and Chapman, 2003), a process of wind-driven shelf-break upwelling may have been triggered by the retreat of the ice beyond the shelf-break observed in 2007. 
Overall, our modelling study highlights the significance of the Arctic Ocean as an area where physical factors play a dominant role in controlling plankton productivity. Given this elevated role for physics, we investigated the possibility of statistically relating production to environmental variables including short-wave radiation (surface and UMLintegrated), UML depth, temperature, salinity and upwelling rates. We found (Sect. 3.5) that the spatial distribution of primary production and its inter-annual variability could be successfully predicted using a simple linear regression relating primary production to annual short-wave radiation and the maximum depth of winter mixing. The spatial distributions of annual primary production in the AO obtained from the full ecosystem model and from the simple regression model (Fig. 10) show the same features of variability, such as elevated levels of productivity in areas affected by the Pacific and Atlantic inflows and a general decline towards the central Arctic. The major discrepancy occurs in the areas where horizontal advection of nutrients plays a significant role. These areas include the southern part of the Chukchi sea where primary production is underestimated in the regression model, and the Norwegian Sea, where the area of high productivity is somewhat distorted.

The ability to correlate primary production with light and depth of mixing presents interesting opportunities for estimating future changes in Arctic productivity from the output of physical climate models, without actually running fully coupled ecosystem models (which represent a significant cost for such simulations). The two independent variables in the regression analysis, short-wave radiation and the depth of winter mixing, may both be expected to change significantly as a result of climate change in the AO. Another interesting potential application of the regression model is within the context of model inter-comparison projects (e.g. AOMIP Proshutinky and Kowalik, 2007), where different physical models follow an identical simulation protocol. Adding the two physical fields described above to the standard output of inter-comparison protocol would give an indication of the uncertainty of the primary production estimates due to the hydrodynamical model configuration, physical parameterisations and forcing. In addition this approach might provide interesting insights into the sensitivity of the $\mathrm{AO}$ ecosystem to uncertainty in the description of the underlying physical fields.

\section{Conclusions}

1. Multi-decadal predictions, for the period 19882006, were undertaken using a global coupled iceocean-ecosystem high resolution model (NEMO-LIM2MEDUSA) with analysis focused on the Arctic domain. Simulated distributions of ice distribution, primary production, biogenic nutrients and chlorophyll, including the presence of a deep chlorophyll maximum through- out much of the study area, showed good agreement with available in-situ and satellite data. Predicted ice edge blooms were however not as intense as those seen in observations, highlighting a need for future work aimed at improving the modelled ice distribution.

2. Model results indicate that productivity of the $\mathrm{AO}$ is heavily influenced by physical factors controlling nutrient supply and light availability. Significant riverine input and ice melt during the productive season results in the majority of the AO being characterised by a stable stratification that severely restricts vertical nutrient supply leading to nutrient limitation of the primary production in surface waters. Scarcity of nutrients at the ocean surface, in combination with light penetrating from above, also leads to the formation of a strong subsurface Chl- $a$ maximum that fuels a substantial part $(\sim 46 \%)$ of the AO primary production. Thus, an accurate description of both light field and nutrient supply is required in order to realistically model productivity in the AO.

3. Model results show that a substantial part ( $\sim 35-40 \%)$ of AO primary production is sustained in ice covered areas. Thus ice concentration, as well as ice extent, is one of he major factors controlling primary production. Improvements in the representation of ice concentration is therefore a high priority for modellers involved in predicted present day and future trends in AO primary production.

4. Primary production in the $\mathrm{AO}$ was empirically correlated with two factors - average short-wave radiation at the ocean surface (under the ice if present) and the maximum depth of winter mixing. These factors show substantial spatial variability in the $\mathrm{AO}$ and explained up to $85 \%$ of spatial variability in the modelled primary production and about $72 \%$ of its interannual variability. This opens the possibility in future of parameterising, rather than explicitly modelling, primary production in modelling studies of the Arctic, particularly those involving longer runs and ensemble simulations.

Acknowledgements. We wish to acknowledge funding of this work from the Natural Environment Research Council, UK, as part of the Oceans2025 (Themes 2 and 9) and Ocean Acidification programmes.

Edited by: E. Boss

\section{References}

Aagaard, K., Coachman, L. K., and Carmack, E. C.: On the halocline of the Arctic Ocean, Deep-Sea Res., 28, 529-545, 1981.

ACIA (Arctic Climate Impact Assessment): Impacts of a warming Arctic; Arctic Climate Impact Assessment. Cambridge University press, Cambridge, 139 pp., 2004. 
Apollonio, S.: Hydrobiological measurements on IGY Drifting Station Bravo, Transactions, American Geophysical Union 40, 316 pp., 1959.

Arakawa, A.: Computational design of long-term numerical integration of the equations of fluid motion, J. Comput. Phys., 1, 119-143, 1966.

Armstrong, R. A., Lee, C., Hedges, J. I., Honjo, S., and Wakeham, S. G.: A new, mechanistic model for organic carbon fluxes in the ocean: based on the quantitative association of POC with ballast minerals, Deep Sea Res. II, 49, 219-236, 2002.

Arrigo, K. R., van Dijken, G. L., and Pabi, S.: Impact of a shrinking Arctic ice cover on marine primary production, Geophys. Res. Lett., 35, L19606, doi:10.1029/2008GL035028, 2008.

Banse, K.: Clouds, deep chlorophyll maxima and the nutrient supply to the mixed layer of stratified water bodies, J. Plankton Res., 9, 1031-1036, 1987.

Barnier B., Madec, G., Penduff, T., Molines, J.-M., Treguier, A.M., Le Sommer, J., Beckmann, A., Biastoch, A., Böning, C., Dengg, J., Derval, C., Durand, E., Gulev, S., Remy, E., Talandier, C., Theetten, S., Maltrud, M., McClean, J., and De Cuevas, B.: Impact of partial steps and momentum advection schemes in a global ocean circulation model at eddy permitting resolution, Ocean Dyn., 56, 543-567, doi:10.1007/s10236-006-0082$1,2009$.

Bates, N. R. and Mathis, J. T.: The Arctic Ocean marine carbon cycle: evaluation of air-sea $\mathrm{CO}_{2}$ exchanges, ocean acidification impacts and potential feedbacks, Biogeosciences, 6, 2433-2459, doi:10.5194/bg-6-2433-2009, 2009.

Brodeau, L., Barnier, B., Penduff, T., Treguier, A.-M., and Gulev, S.: An ERA 40 based atmospheric forcing for global ocean circulation models, Ocean Modell., 31, 88-104, 2010.

Carmack, E. C. and Chapman, D. C.: Wind-driven shelf/basin exchange on an Arctic shelf: The joint roles of ice cover extent and shelf-break bathymetry, Geophys. Res. Lett., 30(14), 1778, doi:10.1029/2003GL017526, 2003.

Carmack, E., Barber, D., Christensen, J. H., Macdonald, R., Rudels, B., and Sakshaug, E.: Climate variability and physical forcing of the food webs and the carbon budget on panarctic shelves, Prog. Oceanogr., 72, 145-181, doi:10.1016/j.pocean.2006.10.005, 2006.

Carmack, E. and Wassmann, P.: Food webs and physicalbiological coupling on pan-Arctic shelves: Unifying concepts and comprehensive perspectives, Prog. Oceanogr., 71, 446-477, doi:10.1016/j.pocean.2006.10.004, 2006.

Conkright, M. E., Antonov, J. I., and Baranova, O.: World Ocean Database 2001, vol. 1, Introduction [CD-ROM], NOAA Atlas NESDIS, vol. 42, edited by: Levitus, S., 159 pp., Govt. Print. Off., Washington, DC, 2002.

Cota, G. F., Pomeroy, L. R., Harrison, W. G., Jones, E. P., Peters, F., Sheldon, W. M., and Weingartner, T. R.: Nutrients, primary production and microbial heterotrophy in the southeastern Chukchi Sea: Arctic summer nutrient depletion and heterotrophy, Mar. Ecol. Prog. Ser., 135, 247-258, 1996.

Cuny, J., Rhines, P., and Kwok, R.: Davis Strait volume, freshwater and heat fluxes, Deep-Sea Res. Part I, 52, 519-542, 2005.

Curry, B., Lee, C. M., Petrie, B.: Volume, freshwater and heat fluxes through Davis Strait, 2004-2005, Geophys. Res. Lett., in press, 2010.

Dai, A. and Trenberth, K. E.: Estimates of freshwater discharge from continents: latitudinal and seasonal variations, J. Hydroeteorol., 3, 660-687, 2002.

Deser, C., Walsh, J. E., and Timlin, M. S.: Arctic Sea Ice Variability in the Context of Recent Atmospheric Circulation Trends, J. Climate, 13, 617-633, doi:10.1175/1520-0442, 2000.

DRAKKAR Group: Eddy-permitting Ocean Circulation Hindcasts of past decades, CLIVAR Exchanges No 42, 12(3), 8-10, 2007.

Dugdale, R. C. and Goering, J. J.: Uptake of new and regenerated forms of nitrogen in primary productivity, Limnol. Oceanogr. 12, 196-206, 1967.

Dunne, J. P., Sarmiento, J. L., and Gnanadesikan, A.: A synthesis of global particle export from the surface ocean and cycling through the ocean interior and on the seafloor, Global Biogeochem. Cy., 21, GB4006, doi:10.1029/2006GB002907, 2007.

Ellingsen, I. H., Dalpadado, P., Slagstad, D., and Loeng, H.: Impact of climatic change on the biological production in the Barents Sea, Climate Change, 87, 155-175, doi:10.1007/s10584007-9369-6, 2008.

English, T. S.: Some biological oceanographic observations in the central north Polar Sea, Drift Station Alpha, 1957-1958, Arctic Inst. of North America Scientific Report No. 13, 1961.

Fichefet, T. and Morales Maqueda, M. A.: Sensitivity of a global sea ice model to the treatment of ice thermodynamics and dynamics, J. Geophys. Res., 102(C6), 12609-12646, 1997.

Flato, G. and Boer, G. J.: Warming asymmetry in climate change simulations, Geophys. Res. Lett., 28, 195-198, 2001.

Gosselin, M., Levasseur, M., Wheeler, P. A., Horner, R. A., and Booth, B. C.: New measurements of phytoplankton and ice algal production in the Arctic Ocean, Deep Sea Res. II, 44, 1623 1644, 1997.

Grebmeier, J. M., Cooper, L. W., Feder, H. M., and Sirenko, B. I.: Ecosystem Dynamics of the Pacific-Influenced Northern Bering and Chukchi Seas, Prog. Oceanogr., 71, 331-361, 2006.

Hibler III, W. D.: A dynamic thermodynamic sea ice model, J. Phys. Oceanogr., 9(4), 815-846, 1979.

Hill, V. and Cota, G.: Spatial patterns of primary production on the shelf, slope and basin of the Western Arctic in 2002, Deep-Sea Res. II, 52, 3344-3354, doi:10.1016/j.dsr2.2005.10.001, 2005.

Hutchings, J. K. and Hibler III, W. D.: Small-scale sea ice deformation in the Beaufort Sea seasonal ice zone, J. Geophys. Res., 113, C08032, doi:10.1029/2006JC003971, 2008.

Ivanov, V. V. and Golovin, P. N.: Observations and modeling of dense water cascading from the northwestern Laptev Sea shelf, J. Geophys. Res., 112, C09003, doi:10.1029/2006JC003882, 2007.

Ivanov, V. V. and Shapiro, G. I.: Formation of a dense water cascade in the marginal ice zone in the Barents Sea, Deep-Sea Res. Part I, 52, 1699-1717, 2005.

Jourdan, D., Balopouls, E., Garcia-Fernandez, M. J., and Maillard, C.: Objective analysis of temperature and salinity historical data set over the Mediterranean Basin, IEEE Press, Piscataway, NJ, 1998.

Kirchman, D. L., Hill, V., Cottrell, M. T., Gradinger, R., Malmstrom, R. R., and Parker, A.: Standing stocks, production and respiration of phytoplankton and heterotrophic bacteria in the western Arctic Ocean, Deep-Sea Res II, 56, 1237-1248, doi:10.1016/j.dsr2.2008.10.018, 2009.

Lalande, C., Belanger, S., and Fortier, L.: Impact of a decreasing sea ice cover on the vertical export of particulate organic carbon in the northern Laptev Sea, Siberian Arctic Ocean, Geophys. Res. 
Lett., 36, L21604, doi: 10.1029/2009GL040570, 2009.

Large W. G. and Yeager, S. G.: Diurnal to decadal global forcing for ocean and sea-ice models: The data sets and flux climatologies, Technical Report TN-460+STR, NCAR, 105 pp., 2004.

Lengaigne, M., Madec, G., Bopp, L., Menkes, C., Aumont, O., and Cadule, P.: Bio-physical feedbacks in the Arctic Ocean using an Earth system model, Geophys. Res. Lett., 36, L21602, doi:10.1029/2009GL040145, 2009.

Levitus, S., Boyer, T. P., Conkright, M. E., O’Brian, T., Antonov, J., Stephens, C., Stathopolos, L., Johnson, D., and Gelfeld, R.: World ocean database 1998. NOAA Atlas NESDID 18, US Government Printing Office, Washington, DC, 1998.

Lique, C., Treguier, A.-M., Scheinert, M., and Penduff, T.: A model-based study of ice and freshwater transport variability along both sides of Greenland, Clim. Dyn., 33, 685-705, doi:10.1007/s00382-008-0510-7, 2009.

Liu, A. K., Häkkinen, S., and Peng, C. Y.: Wave Effects on OceanIce Interaction in the Marginal Ice Zone, J. Geophys. Res., 98(C6), 10025-10036, doi:10.1029/93JC00653, 1993.

Madec, G., Delecluse, P., Imbard, M., and Levy, C.: OPA 8.1 ocean general circulation model reference manual, IPSL Tech. Rep. Tech Rep. 11, Institut Pierre-Simon Laplace, 91 pp., 1998.

Madec, G.: NEMO reference manual, ocean dynamic component: NEMO-OPA. Rep. 27, Note du ple de modlisation, Institut Pierre Simmon Laplace (IPSL), France, ISSN No. 1288-1619, 2008.

Martin, J. H., Knauer, G. A., Karl, D. M., and Broenkow, W. W.: VERTEX: Carbon cycling in the northeastern Pacific, Deep-Sea Res. I, 34, 267-285, 1987.

Melling, H., Agnew, T. A., Falkner, K. K., Greenberg, D. A., Lee, C. M., Münchow, A., Petrie, B., Prinsenberg, S. J., Samelson, R. M., and Woodgate, R. A.: Fresh-water fluxes via Pacific and Arctic Outflow across the Canadian Polar Shelf, Arctic-Subarctic Ocean Fluxes: Defining the Role of the Northern Seas in Climate, edited by: Dickson, R. R., Meincke, J., and Rhines, P., Springer Verlag, The Netherlands, 193-248, 2008.

Melnikov, I. A., Kolosova, E. G., Welch, H. E., and Zhitina, L. S.: Sea Ice biological communities and nutrient dynamics in the Canada Basin of the Arctic Ocean, DSR I, 49, 1623-1649, 2002.

Merryfield, W. J. and Holloway, G.: Application of an accurate advection algorithm to sea-ice modelling, Ocean Mod., 5(1), 1-15, ISSN 1463-5003, doi:10.1016/S1463-5003(02)00011-2, 2003.

McPhee, M. G., Stanton, T. P., Morison, J. H., and Martinson, D. G.: Freshening of the upper ocean in the Arctic: is perennial sea ice disappearing?, Geophys. Res. Lett., 25, 1729-1732, 1998.

Michel, C., Ingram, R. G., and Harris, L. R.: Variability in Oceanographic and Ecological Processes in the Canadian Arctic Archipelago, Prog. Oceanogr., 71, 379-401, doi:10.1016/j.pocean.2006.09.006, 2006.

Mongin, M., Nelson, D. M., Pondaven, P., and Tréguer, P.: Simulation of upper-ocean biogeochemistry with a flexible-composition phytoplankton model: $\mathrm{C}, \mathrm{N}$ and Si cycling and Fe limitation in the Southern Ocean, Deep-Sea Res. II, 53, 601-619, 2006.

Mundy, C. J., Gosselin, M., Ehn, J., Gratton, Y., Rossnagel, A., Barber, D. G., Martin, J., Tremblay, J. E., Palmer, M., Arrigo, K. R., Darnis, G., Fortier, L., Else, B. G. T., and Papakyriakou, T. N.: Contribution of under-ice primary production to an ice-edge upwelling plhytoplankton bloom in the Canadian Beaufort Sea, Geophys. Res. Lett., 36, L17601, doi:10.1029/2009GL038837, 2009.
Niebauer, H. J. and Alexander, V.: Oceanographic frontal structure and biological production at an ice edge, Cont. Shelf Res., 4, 367-388, doi:10.1016/0278-4343(85)90001-9, 1985.

Niebauer, H. J., Alexander, V., and Henrichs, S.: Physical and biological oceanographic interaction in the spring bloom at the Bering Sea marginal ice zone, J. Geophys. Res., 95, 2222922241, 1990.

Niebauer, H. J., Alexander, V., and Cooney R. T.: Primary production at the Eastern Bering Sea ice edge: the physical and biological regimes, in: The Eastern Bering Sea Shelf: Oceanography and Resources, edited by: Hood D. W. and Calder J. A., University of Washington Press, Seattle, vol. II, 763-772, 1990.

Niebauer, H. J. and Smith Jr., W. O.: A Numerical Model of Mesoscale Physical-Biological Interactions in the Fram Strait Marginal Ice Edge Zone, J. Geophys. Res., 94, 16151-16175, 1989.

Nitishinsky, M., Anderson, L. G., and Hölemann, J. A.: Inorganic carbon and nutrient fluxes on the Arctic Shelf, Cont. Shelf Res. 27(10-11), 1584-1599, doi:10.1016/j.csr.2007.01.019, 2007.

Olsen, A., Johannessen, T., and Rey, F.: On the nature of the factors that control spring bloom development at the entrance to the Barents Sea and their interannual variability, Sarsia, 88, 379-393, doi:10.1080/00364820310003145, 2003.

Overland, J., Walter, B., Curtin, T. B., and Turet, P.: Hierarchy and sea ice mechanics: A case study from the Beaufort Sea, J. Geophys. Res., 100(C3), 4559-4571, 1995.

Pabi, S., Van Dijken, G. L., and Arrigo, K.: Primary production in the Arctic Ocean, 1998-2006, J. Geophys. Res., 113, C08005, doi:10.1029/2007JC004578, 2008.

Parekh, P., Follows, M. J., and Boyle, E. A.: Decoupling of iron and phosphate in the global ocean, Global Biogeochem. Cy., 19, GB2020, doi:10.1029/2004GB002280, 2005.

Parekh, P., Dutkiewicz, S. Follows, M. J., and Ito, T.: Atmospheric carbon dioxide in a less dusty world, Geophys. Res. Lett., 33, L03610, doi:10.1029/2005GL025098, 2006.

Payne, R. E.: Albedo at the sea surface, J. Atmos. Sci., 29, 959-970, 1972.

Penduff, T., Le Sommer, J., Barnier, B., Treguier, A.-M., Molines, J.-M., and Madec, G.: Influence of numerical schemes on current-topography interactions in $1 / 4^{\circ}$ global ocean simulations, Ocean Sci., 3, 509-524, doi:10.5194/os-3-509-2007, 2007.

Penduff, T., Juza, M., Brodeau, L., Smith, G. C., Barnier, B., Molines, J.-M., Treguier, A.-M., and Madec, G.: Impact of global ocean model resolution on sea-level variability with emphasis on interannual time scales, Ocean Sci., 6, 269-284, doi:10.5194/os6-269-2010, 2010.

Perrette, M., Yool, A., Quartly, G. D., and Popova, E. E.: Nearubiquity of ice-edge blooms in the Arctic, Biogeosciences Discuss., 7, 8123-8142, doi:10.5194/bgd-7-8123-2010, 2010.

Perovich, D. K., Richter-Menge, J. A., Jones, K. F., and Light, B.: Sunlight, water, and ice: Extreme Arctic sea ice melt during the summer of 2007, Geophys. Res. Lett., 35, L11501, doi:10.1029/2008GL034007, 2008.

Popova, E. E., Coward, A. C., Nurser, G. A., de Cuevas, B., Fasham, M. J. R., and Anderson, T. R.: Mechanisms controlling primary and new production in a global ecosystem model - Part I: Validation of the biological simulation, Ocean Sci., 2, 249-266, doi:10.5194/os-2-249-2006, 2006.

Popova, E. E., Coward, A. C., Nurser, G. A., de Cuevas, B., and 
Anderson, T. R.: Mechanisms controlling primary and new production in a global ecosystem model - Part II: The role of the upper ocean short-term periodic and episodic mixing events, Ocean Sci., 2, 267-279, doi:10.5194/os-2-267-2006, 2006.

Prather, M. C.: Numerical advection by conservation of second-order moments, J. Geophys. Res., 91, doi:10.1029/JD091iD06p06671, 1986.

Proshutinsky, A. and Kowalik, Z.: Preface to special section on Arctic Ocean Model Intercomparison Project (AOMIP) Studies and Results, J. Geophys. Res., 112, C04S01, doi:10.1029/2006JC004017, 2007.

Rainville, L. and Woodgate, R. A.: Observations of internal wave generation in the seasonally ice-free Arctic, Geophys. Res. Lett., 36, L23604, doi:10.1029/2009GL041291, 2009.

Rayner, N. A., Parker, D. E., Horton, E. B., Folland, C. K., Alexander, L. V., Rowell, D. P., Kent, E. C., and Kaplan, A.: Global analyses of sea surface temperature, sea ice, and night marine air temperature since the late nineteenth century J. Geophys. Res., 108(D14), 4407, doi:10.1029/2002JD002670, 2003.

Rudels, B., Anderson, L. G., and Jones, E. P.: Formation and evolution of the surface mixed layer and halocline of the Arctic Ocean, J. Geophys. Res., 101(C4), 8807-8821, 1996.

Sakshaug, E. and Skjoldal, H. R.: Life at the Ice Edge, Ambio, 18, 60-67, 1989.

Sakshaug, E.: Primary and secondary production in the Arctic Seas, in: The Organic Carbon Cycle in the Arctic Ocean, edited by: Stein, R. and Macdonald, R., Springer, 57-81, 2004.

Semtner Jr., A. J.: A model for the thermodynamic growth of sea ice in numerical investigation of climate, J. Phys. Oceanogr., 6, 376-389, 1976.

Schauer, U., Beszczynska-Möller, A., Walczowski, W., Fahrbach, E., Piechura, J., and Hansen, E.: Variation of measured heat flow through the Fram Strait between 1997 and 2006, ArcticSubarctic Ocean Fluxes: Defining the Role of the Northern Seas in Climate, edited by: Dickson, R. R., Meincke, J., and Rhines, P., Springer Verlag, The Netherlands, 65-86, 2008.

Sherr, B. F. and Sherr, E. B.: Community respiration/production and bacterial activity in the upper water column of the central Arctic Ocean, Deep-Sea Res. I, 50, 529-542, 2003.

Slagstad, D. and McClimans, T. S.: Modeling the ecosystem dynamics of the Barents Sea including the marginal ice zone: I. Physical and chemical oceanography, J. Mar. Syst., 58, 1-18, 2005.

Smedsrud, L. H., Ingvaldsen, R., Nilsen, J. E. Ø., and Skagseth, Ø.: Heat in the Barents Sea: transport, storage, and surface fluxes, Ocean Sci., 6, 219-234, doi:10.5194/os-6-219-2010, 2010.

Smith Jr., W. O. and Niebauer, H. J.: Interactions Between Biological and Physical Processes in Arctic Seas: Investigations Using Numerical Models, Rev. Geophys., 31, 189-209, 1993.

Steele, M., Morley, R., and Ermold, W.: PHC: a global ocean hydrography with a high quality Artic Ocean, J Climate, 14, 20792087, 2001.

Squire, V. A.: The marginal ice zone, in: Physics of ice covered seas, edited by: Lepparanta, M., Lecture notes from a summer school in Savonlinna, Finland, 1994, vol. 1, 381-446, Helsinki: Helsinki University Printing House, 1998.

Squire, V. A.: Of ocean waves and sea-ice revisited, Cold. Reg. Sci. Technol., 49(2), 110-133, 2007.

Timmermann, R., Goose, H., Madec, G., Fichefet, T., Ethe, C., and Duliere, V.: On the representation of high latitude processes in the ORCA-LIM global coupled sea ice-ocean model, Ocean Mod., 8, 175-201, 2005.

Tremblay, J.-E. and Gagnon, J.: The effect of irradiance and nutrient supply on the productivity of Arctic waters: a perspective on climate change, in: Influence of Climate Change on the Changing Arctic and Sub-Arctic Conditions, edited by: Nihpul, J. C. J. and Kostianoy, A. G., Springer Science + Business Media B.V., 2009.

Tsuda, A., Takeda, S., Saito, H., et al.: A Mesoscale Iron Enrichment in the Western Subarctic Pacific Induces a Large Centric Diatom Bloom, Science, 300, 958-961, doi:10.1126/science.1082000, 2003.

Vetrov, A. A., Romankevich, E. A., and Belyaev, N. A.: Chlorophyll and primary production, flows, and balance of organic carbon in the Laptev Sea, Geochemistry International, 46, 1055-1063, 2008.

Vetrov, A. A.: Chlorophyll, Primary Production, and. Organic Carbon Fluxes in the Kara Sea, Oceanology, 48, 38-41, 2008.

Vinnikov, K. Y., Robock, A., Stouffer, R. J., Walsh, J. E., Parkinson, C. L., Cavalieri, D. J., Mitchell, J. F. B., Garrett, D., and Zakharov, V. F.: Global warming and northern hemisphere sea ice extent, Science, 286, 1934-1937, 1999.

Wadhams, P.: The seasonal ice zone, in: The Geophysics of Sea Ice, edited by: Untersteiner, N., 825-991, NATO ASI Series B: Physics Vol. 146, NY, 1986.

Wassmann, P., Slagstad, D., Riser, C. W., and Reigstad, M.: Modelling the ecosystem dynamics of the Barents Sea, including the marginal ice zone II. Carbon flux and interannual variability, J. Mar. Syst., 59, 1-24, 2006.

Walsh, J. J., Dieterle, D. A., Maslowski, M., and Whitledge, T. E.: Decadal shifts in biophysical forcing of marine food webs in the Arctic: numerical consequences, J. Geophys. Res., 109, C05031, doi:10.1029/2003JC001945, 2004.

Walsh, J. J., Dieterle, D. A., Maslowski, W., Grebmeier, J. M., Whitledge, T. E., Flint, M., Sukhanova, I. N., Bates, N., Cota, G. F., Stockwell, D., Moran, S. B., Hansell, D. A., and McRoy, C. P.: A numerical model of seasonal primary production within the Chukchi/Beaufort Seas, Deep-Sea Res. II, 52, 3541-3576, doi:10.1016/j.dsr2.2005.09.009, 2005.

Woodgate, R., Aagaard, K., and Weingartner, T.: A year in the physical oceanography of the Chukchi Sea: moored measurements from autumn 1990-1991, Deep-Sea Res. II, 52, 31163149, doi:10.1016/j.dsr2.2005.10.016, 2005.

Wu, P., Wood, R., and Stott, P.: Human influence on increasing Arctic river discharges, Geophys. Res. Lett., 32, 5593, doi:10.1029/2004GL021570, 2005.

Yang, J., Comiso, J., Walsh, D., Krishfield, R., and Honjo, S.: Storm-driven mixing and potential impact on the Arctic Ocean, J. Geophys. Res., 109, C04008, doi:10.1029/2001JC001248, 2005.

Yool, A., Popova, E. E., and Anderson, T. R.: MEDUSA: a new intermediate complexity plankton ecosystem model for the global domain, Geosci. Model Dev. Discuss., 3, 1939-2019, doi:10.5194/gmdd-3-1939-2010, 2010.

Zhang, J., Spitz, Y. H., Steele, M., Ashjian, C., Campbell, R., Berline, L., and Matrai, P.: Modeling the Impact of Declining Sea Ice on the Arctic Marine Planktonic Ecosystem, J. Geophys. Res.-Ocean, accepted, 2010. 